\title{
Molecular Genetic Characterization of Shiga Toxin-producing E. coli Isolated from Diarrhea Patients and Cattle in Gwangju Area, Korea
}

\author{
Min Ji Kim ${ }^{1 *}$, Sun Hee Kim ${ }^{1}$, Tae Sun Kim ${ }^{1}$, Hye-young Kee ${ }^{1}$, Jin-jong Seo ${ }^{1}$, Eun-Sun Kim ${ }^{1}$, \\ Jong-Tae Park ${ }^{1}$, Jae Keun Chung ${ }^{1}$, Bok Kwon Lee ${ }^{2}$ and Jaeil Lee ${ }^{3}$ \\ ${ }^{1}$ Health \& Environment Institute of Gwangju, Gwangju, Korea \\ ${ }^{2}$ Center for Infectious Diseases, National Institute of Health, Seoul, Korea \\ ${ }^{3}$ Department of Veterinary Medicine, Chonnam National University, Gwangju, Korea
}

\begin{abstract}
Shiga toxin-producing Escherichia coli (STEC) can cause a broad spectrum of human illness ranging from symptomfree to hemolytic uremic syndrom (HUS). Associations between known or putative virulence factors of STEC and diseases in human were investigated. PCR analyses showed that $33(78.6 \%)$ isolates carried an ehxA enterohemolysin gene and $6(14.3 \%)$ isolates possessed an saa autoaggutinating adhesin gene, and $31(73.8 \%)$ isolates carried an eae intimin gene ( 7 isolates with type $\beta, 16$ with type $\gamma$, and 3 with type $\varepsilon$ ). Twenty-nine (69\%) isolates from patients carried $e a e^{+}, e h x A^{+}$, saa- (genotype A) and $68(86 \%)$ isolates from asymptomatic outbreaks and 4 (36\%) isolates from bovine possessed eae-, ehxA+, saa+ (genotype $\mathrm{C}$ ). Neither the bundle-forming pilus gene nor the enteropathogenic E. coli adherence factor plasmid was found. In HEp-2 cell adherence assay, isolates carrying eae gene exhibited a localized adherence phenotype, the other isolates carrying saa showed LC (loose clusters of bacteria) and IS (isolated bacteria). In conclusion, most STEC isolated from cattle feces in Gwangju, Korea showed characteristics different from those isolated from patients. But these results may be useful information for pathogenesis judgement of STEC.
\end{abstract}

Key Words: Shiga toxin-producing Escherichia coli, saa, ehxAx, eae, HEp-2 cell adherence assay

\section{서 론}

시가 독소생성 대장균 (shiga toxin-producing E. coli, $\mathrm{STEC})$ 은 무증상에서 수양성설사, 혈성설사, 출혈성장염, 용혈성 요독증후군 (hemolytic uremic syndrome, HUS) 등 에 이르기까지 다양한 임상증상을 나타낸다. HUS는 급성 신부전, 혈소판감소증, 미세혈관병성 용혈성빈혈이 특징 인 증후군으로써 혈성설사를 시작한 지 1 주일 후 특징

Received: March 25, 2009/ Revised: April 7, 2009

Accepted: April 20, 2009

* Corresponding author: Min Ji Kim. Health \& Environment Institute of Gwangju, 898 Hwajung-dong, Seo-gu, Gwangju 502-837, Korea.

Phone: +82-62-380-1833, Fax: +82-62-380-1836

e-mail: vetmj@korea.kr

** This research was performed as a part of the laboratory surveillance of acute diarrhea, managed by the National Institute of Health, Republic of Korea.
적인 증상이 나타나고 소아 급성신부전 등의 원인으로 사망률이 매우 높다. 또한 출혈성장염은 복통과 물설사 후에 하부 위장관 출혈과 유사한 혈변이 발생하는 질환 으로 발열이 있지만 혈액내 백혈구수의 증가가 없는 것 이 다른 염증성장염과 차이가 있다. 이러한 임상증상은 O157:H7에서 전형적으로 나타나며, non-O157:H7과는 정 도의 차이가 있을 뿐이지 임상적으로 특별하게 구별되지 는 않는다 (1).

병원성이 높은 STEC 균주는 enterohemorrhagic E. coli (EHEC)로 명명되고 있으며 (2), 0157 이외에도 여러 가 지 혈청형이 알려져 있지만, 시가 독소 유전자를 가진 STEC 균주가 모두 시가 독소를 생산하는 것은 아니기 때문에 독소 생산여부를 반드시 검사해야 한다. 또한 시 가 독소를 생산하는 대장균에서도 Stx1만을 생산하는 것 과 Stx2만을 생산하는 것 그리고 모두를 동시에 생산하 는 것으로 분류하고 있는데, 실제로 어느 시가 독소를 
생산하느냐에 따라서 병원성의 정도에 차이가 있다 (3). $\mathrm{STEC}$ 는 시가 독소 외에 장관상피세포의 세포질막에 부착하여 장관의 미세융모를 소멸시키고, $\operatorname{actin}$ 을 축적 시켜 세포골격을 변화시키는 특징적인 장관병변 즉 "attaching and effacing lesion" (A/E lesion) 또한 STEC의 중요한 병소이다 (4). 이와 같은 $\mathrm{A} / \mathrm{E}$ 병변에 필수적인 eae 유전자는 LEE (locus of enteocyte effacement)로 알려져 있는 $35.5 \mathrm{~kb}$ 크기의 염색체상의 병원성섬 (pathogenicity island, PAI)에 위치하고 있으며, 94 97 kDa 크기의 외막 단백질인 intimin을 지령한다 (5). LEE는 intimin 이외에 도 제3형 분비계 (type III secretion system, TTSS)와 그것 에 의해 분비되는 Tir (translocated intimin receptor), Esp (EPEC-secreted protein) 등 병원성에 관련된 여러 종류의 단백질을 지령하고 있다. Intimin을 가진 STEC와 임상증 상과의 연관관계는 이미 밝혀졌지만, 이것이 반드시 필수 적인 병원성 인자는 아니다. Adhesin과 pili와 같은 부착인 자들이 eae 음성인 균주에서도 확인되었고 $(6,7)$, 이들 균주와 특정 혈청형을 가진 STEC가 혈변 및 HUS와 관 계가 있다고 보고되었다 (8). 하지만 이러한 intimin이 결 여된 STEC들의 병원성 기작에 대한 연구는 아직 미비 하다.

이 외에도 enterohemolysin 유전자인 $e h x A$, catalase peroxidase $k a t P$, 제2형 분비계와 관련있는 etp 유전자 그 리고 secreted serine protease (EspP) 등이 EHEC의 병원성 과 연관이 있다고 보고되었다 (9 12).

$\mathrm{STEC}$ 는 미국, 영국, 캐나다 뿐 만 아니라 일본, 인도, 중국 등 아시아 지역에서도 보고되고 있지만, 일본 이외 의 아시아 지역에서 분리된 균주들에 대한 특성은 잘 밝 혀져 있지 않으며 (13). 이들에 대한 연구가 대부분 HUS 와 같은 심각한 임상증상이 나타난 환자에서 분리된 균 주를 대상으로 한 결과로, 실제 무증상이나 경미한 설사 만을 일으키는 균주를 대상으로 한 병원성 기작에 대한 연구는 미흡한 실정이다. 또한 국내에서 소 분리주 STEC 특성에 대한 연구도 전무한 상태이다.

따라서 본 연구에서는 설사환자 분리주와 무증상 집단 감염주, 소 분변으로부터 분리된 STEC를 대상으로 병원 성 유전자의 특징을 비교 검토하였다. 그리고 지역 내 유행하는 시가 독소생성 대장균의 유형파악 및 병인기작 을 밝혀 이를 바탕으로 장출혈성대장균 감염증 제어를 위한 대책을 수립하는데 기초 자료를 마련하고자 하였다.

\section{재료 및 방법}

\section{시가 독소생성 대장균 병원성관련 유전자 검출}

설사환자 분리주와 무증상 집단감염 분리주 및 소 분 변 유래 분리주간의 상관관계를 살펴보기 위해 $\mathrm{PCR}$ 을 이용하여 병원성 유전자를 검출하였다.

saa, ehxA, eae 유전자 multiplex PCR

실험균주

설사환자 및 접촉자 그리고 식중독으로 의뢰된 검체 에서 분리된 STEC 42주와 2004년 J 초등학교 무증상 집단감염으로부터 분리된 STEC 79주 및 소 분변 유래 STEC 11주를 실험에 사용하였다. 양성 대조균주로는 ATCC 43895 (EDL 933)를 사용하였다.

STEC 분리주는 TSA (Tryptic soy agar, Oxoid, Hampshire, $\mathrm{UK})$ 에 계대 배양한 다음, 미량의 균체를 멸균증류수 500 $\mu \mathrm{l}$ 에 현탁시켜 10 분간 끓는 물에서 중탕하고 $14,000 \mathrm{rpm}$ 에서 10 분간 원심 분리한 후 상층액을 DNA template로 이용하였다.

\section{Premix 제조 및 PCR 조건}

saa, ehxA, eae 유전자 검출에 사용된 primer는 Paton (14) 등에 의한 것으로 Table 1과 같다. PCR 반응액 조성 은 $200 \mathrm{mM} \mathrm{dNTP}$, 각각의 primer $250 \mathrm{nM}, 5 \mathrm{mM} \mathrm{MgCl}_{2}$ 가 포함된 $10 \times$ buffer, $1 \mathrm{U}$ 의 Taq DNA polymerase (Bioneer, Daejeon, Korea) 그리고 멸균증류수로 $50 \mu \mathrm{l}$ 의 반응 혼합 액을 제조하였다.

$\mathrm{PCR}$ 조건은 1 차 반응에서 $95^{\circ} \mathrm{C} / 5$ 분간 denaturation 후, $95^{\circ} \mathrm{C} / 1$ 분, $65^{\circ} \mathrm{C} / 2$ 분, $72^{\circ} \mathrm{C} / 1$ 분 30 초의 cycle을 10 회 실시하 였고, 2 차 반응에서 $95^{\circ} \mathrm{C} / 1$ 분, $60^{\circ} \mathrm{C} / 2$ 분, $72^{\circ} \mathrm{C} / 1$ 분 30 초의 cycle을 15 회 실시한 후, $95^{\circ} \mathrm{C} / 1$ 분, $60^{\circ} \mathrm{C} / 2$ 분, $72^{\circ} \mathrm{C} / 2$ 분 30 초의 cycle을 10 회로 3 차 반응을 실시하였다. 마지막으로 $72^{\circ} \mathrm{C}$ 에서 2 분 30 초간 반응시켰다. $\mathrm{PCR}$ 을 수행한 후 $5 \mu \mathrm{l}$ 의 $\mathrm{PCR}$ 산물을 $2 \%$ agarose gel에 전기영동한 후 $\mathrm{EtBr}$ 에 염색하여 UV하에서 확인하였다.

\section{LEE 관련 유전자 검출}

\section{실험균주}

설사환자 및 접촉자 그리고 식중독으로 의뢰된 검체에 서 분리된 STEC 42주와 2004년 J 초등학교 무증상 집단 발병으로부터 분리된 STEC 중 위의 $s a a, e h x A$, eae 유형 별로 분리한 14주 (식품 유래 분리주 2주 포함) 및 소 분 변 유래 STEC 11주를 대상으로 PCR을 실시하였고 양성 
대조군으로 ATCC 43895 (EDL 933)를 사용하였다.

STEC 분리주 각각을 TSA에 계대 배양한 다음, 미량 의 균체를 멸균증류수 $500 \mu \mathrm{l}$ 에 현탁시켜 10 분간 끓는
물에서 중탕하고 $14,000 \mathrm{rpm}$ 에서 10 분간 원심 분리한 후 상층액을 DNA template로 이용하였다. 각각의 유형분석 에 사용된 primer에 대한 목록은 Table 1과 같다.

Table 1. PCR primers to amplify specific fragments from the various pathogenic genes in STEC

\begin{tabular}{|c|c|c|c|c|}
\hline PCR primer & Target gene (s) & Sequence $\left(5^{\prime}-3^{\prime}\right)$ & Size of product (bp) & Reference \\
\hline SAADF & saa & CGTGATGAACAGGCTATTGC & 119 & 14 \\
\hline SAADR & & ATGGACATGCCTGTGGCAAC & & \\
\hline eaeAF & eae & GACCCGGCACAAGCATAAGC & 384 & 19 \\
\hline eaeAR & & CCACCTGCAGCAACAAGAGG & & \\
\hline hlyAF & $e h x A$ & GCATCATCAAGCGTACGTTCC & 534 & 19 \\
\hline hlyAR & & AATGAGCCAAGCTGGTTAAGCT & & \\
\hline B73 & eae $\alpha$ & TACTGAGATTAAGGCTGATAA & 452 & 16 \\
\hline B138 & & GACCAGAAGAAGATCCA & & \\
\hline B73 & eae $\beta$ & TACTGAGATTAAGGCTGATAA & 520 & 16 \\
\hline B137 & & TGTATGTCGCACTCTGATT & & \\
\hline B73 & eae $\gamma$ & TACTGAGATTAAGGCTGATAA & 778 & 16 \\
\hline B74 & & AGGAAGAGGGTTTTGTGTT & & \\
\hline Int $\delta$ & eae $\delta$ & TACGGATTTTGGGGCAT & 125 & 9 \\
\hline Int-Ru & & TTTATTTGCAGCCCCCCAT & & \\
\hline SK1 & eae $\varepsilon$ & CCCGAATTCGGCACAAGCATAAGC & 2,069 & 9 \\
\hline LP5 & & AGCTCACTCGTAGATGACGGCAAGCG & & \\
\hline Tir-F & tir & CATTACCTTCACAAACCGAC & 1,550 & 20 \\
\hline Tir-R & & CCCCGTTAATCCTCCCAT & & \\
\hline ESPAa & espA & CACGTCTTGAGGAAGTTTGG & 229 & 17 \\
\hline ESPAb & & CCGTTGTTAATGTGAGTGCG & & \\
\hline ESPB-F & $\operatorname{esp} B$ & GCCGTTTTTGAGAGCCAGAAT & 633 & 20 \\
\hline ESPB-R & & ATCATCCTGCGCTCTGCGAAC & & \\
\hline ESPD-F & $\operatorname{espD}$ & CGCTGGATTTACAACTGGTTA & 939 & 20 \\
\hline ESPD-R & & CCAGCTCAACCTTCGCACTCT & & \\
\hline ESPPa & espP & AAACAGCAGGCACTTGAACG & 301 & 17 \\
\hline ESPPb & & AGACAGTTCCAGCGACAACC & & \\
\hline K260 & Disrupted selC & GAGCGAATATTCCGATATACTGGTT & 418 & 18 \\
\hline K255 & & GGTTGAGTCGATTGATCTCTGG & & \\
\hline K260 & Intact selC & GAGCGAATATTCCGATATACTGGTT & 527 & 18 \\
\hline K261 & & CCTGCAAATAAACACGGCGCAT & & \\
\hline BFP1 & $b f p$ & GATTGAATCTGCAATGGTGC & 597 & 21 \\
\hline BFP2 & & GGATTACTGTCCTCACATAT & & \\
\hline EAF1 & EAF plasmid & CAGGGTAAAAGAAAGATGATAA & 399 & 22 \\
\hline EAF25 & & TATGGGGACCATGTATTATCA & & \\
\hline
\end{tabular}


eae 유전자의 유형분석을 위한 multiplex PCR

$e a e$ 유전자에 대하여 $\alpha, \gamma$ 그리고 $\beta$ 유형 결정을 위한 multiplex PCR을 실시하였다 $(15,16)$.

PCR 반응액 조성은 template DNA $5 \mu \mathrm{l}, 2.5 \mathrm{mM}$ dNTP $5 \mu \mathrm{l}, 5 \mathrm{mM} \mathrm{MgCl}_{2}$ 가 포함된 $10 \times$ buffer $5 \mu \mathrm{l}$ 와 각각의 primer $0.5 \mu \mathrm{l}$ 씩, $1 \mathrm{U}$ 의 Taq DNA polymerase와 멸균된 증류 수로 최종 $50 \mu \mathrm{l}$ 로 맞추었다. $\alpha, \gamma$ 그리고 $\beta$ 유형을 결정 하기 위한 primer는 B73을 forward primer로, 각각의 유 형에 따라 B138, B74그리고 B137을 reverse primer로 사 용하였다 (Table 1).

$\mathrm{PCR}$ 조건은 $94^{\circ} \mathrm{C}$ 에서 5 분간의 cycle을 1 회, $94^{\circ} \mathrm{C} / 30$ 초, $50^{\circ} \mathrm{C} / 30$ 초, $72^{\circ} \mathrm{C} / 30$ 초의 cycle을 30 회 실시하고 $72^{\circ} \mathrm{C} / 5$ 분 간 반응시켰다.

$\delta$ 와 $\varepsilon$ 유형을 결정하기 위한 PCR 방법은 Pradel 등 (9) 에 의한 방법으로 $\delta$ 의 $\mathrm{PCR}$ 조건은 $94^{\circ} \mathrm{C} / 2$ 분간의 cycle 을 1 회, $94^{\circ} \mathrm{C} / 1$ 분, $45^{\circ} \mathrm{C} / 1$ 분, $72^{\circ} \mathrm{C} / 1$ 분의 cycle을 30 회 실시 하고 $72^{\circ} \mathrm{C} / 5$ 분간 반응시켰다. $\varepsilon$ 는 $94^{\circ} \mathrm{C} / 2$ 분간의 cycle을 1 회, $94^{\circ} \mathrm{C} / 1$ 분, $55^{\circ} \mathrm{C} / 1$ 분, $72^{\circ} \mathrm{C} / 2$ 분의 cycle을 30 회 실시하고 $72^{\circ} \mathrm{C}$ 에서 5 분간 반응시켰다. $\mathrm{PCR}$ 을 수행한 후 $5 \mu \mathrm{l}$ 의 $\mathrm{PCR}$ 산물을 $2 \%$ agarose gel에 전기영동한 후 $\mathrm{EtBr}$ 에 염 색하여 UV하에서 확인하였다.

tir, $\operatorname{esp} A, \operatorname{espB}, e s p D$ 유전자 분석을 위한 $\mathrm{PCR}$

PCR 반응액 조성은 template DNA $5 \mu \mathrm{l}, 2.5 \mathrm{mM}$ dNTP $5 \mu \mathrm{l}, 5 \mathrm{mM} \mathrm{MgCl}$ 가 포함된 $10 \times$ buffer $5 \mu \mathrm{l}$ 와 각각의 primer $0.5 \mu$ 씩, $1 \mathrm{U}$ 의 Taq DNA polymerase와 멸균된 증류 수로 최종 용량을 $50 \mu \mathrm{l}$ 로 맞추었다. 각각의 유전자 증폭 을 위한 Primer는 Table 1과 같다.

tir 유전자 증폭을 위한 $\mathrm{PCR}$ 조건은 $94^{\circ} \mathrm{C} / 5$ 분간의 cycle을 1 회, $94^{\circ} \mathrm{C} / 40$ 초, $57^{\circ} \mathrm{C} / 60$ 초, $72^{\circ} \mathrm{C} / 75$ 초의 cycle을 30 회 실시하고 마지막 cycle 후 $72^{\circ} \mathrm{C}$ 에서 5 분간 반응시 켰다. espA 유전자 증폭을 위한 $\mathrm{PCR}$ 조건은 $94^{\circ} \mathrm{C} / 5$ 분간 의 cycle을 1 회, $94^{\circ} \mathrm{C} / 45$ 초, $57^{\circ} \mathrm{C} / 45$ 초, $72^{\circ} \mathrm{C} / 90$ 초의 cycle을 30 회 실시하고 마지막 cycle 후 $72^{\circ} \mathrm{C} / 5$ 분간 반응시켰다.

$e s p B$ 와 $e s p D$ 유전자의 $\mathrm{PCR}$ 조건은 annealing 온도가 각각 $63^{\circ} \mathrm{C} / 45$ 초, $60^{\circ} \mathrm{C} / 45$ 초이며 나머지 조건은 espA 유전 자 $\mathrm{PCR}$ 조건과 동일하다. $\mathrm{PCR}$ 을 수행한 후 $5 \mu \mathrm{l}$ 의 $\mathrm{PCR}$ 산물을 2\% agarose gel에 전기영동한 후 $\mathrm{EtBr}$ 에 염색하여 $\mathrm{UV}$ 하에서 확인하였다.

$\mathrm{espP}$ 유전자 검출을 위한 $\mathrm{PCR}$

PCR 반응액 조성은 template DNA $5 \mu \mathrm{l}, 2.5 \mathrm{mM}$ dNTP $5 \mu \mathrm{l}, 5 \mathrm{mM} \mathrm{MgCl}$ 가 포함된 $10 \times$ buffer $5 \mu$ 와 각각의 primer $1 \mu \mathrm{l}$ 씩, $1 \mathrm{U}$ 의 Taq DNA polymerase와 멸균된 증류수 로 최종 $50 \mu \mathrm{l}$ 를 맞추었다.

$\mathrm{PCR}$ 조건은 $94^{\circ} \mathrm{C} / 5$ 분간의 cycle을 1 회, $94^{\circ} \mathrm{C} / 45$ 초, $59^{\circ} \mathrm{C}$ 145 초, $72^{\circ} \mathrm{C} / 90$ 초의 cycle을 30 회 실시하고 마지막 cycle 후 $72^{\circ} \mathrm{C} / 10$ 분간 반응시켰다 (17). $\mathrm{PCR}$ 을 수행한 후 $5 \mu \mathrm{l}$ 의 $\mathrm{PCR}$ 산물을 $2 \%$ agarose gel에 전기영동한 후 $\mathrm{EtBr}$ 에 염색하여 UV하에서 확인하였다.

$\mathrm{LEE}$ 삽입여부 확인 PCR

$\mathrm{STEC}$ 의 selC 유전자상에 LEE 삽입여부를 확인하기 위하여 McDaniel 등 (18)의 방법에 따라 multiplex PCR을 실시하였다.

PCR 반응액 조성은 template DNA $5 \mu \mathrm{l}, 2.5 \mathrm{mM}$ dNTP $5 \mu \mathrm{l}, 5 \mathrm{mM} \mathrm{MgCl}$ 가 포함된 $10 \times$ buffer $5 \mu \mathrm{l}$ 와 각각의 primer $0.5 \mu \mathrm{l}, 1 \mathrm{U}$ 의 Taq DNA polymerase와 멸균된 증류수 로 최종 $50 \mu \mathrm{l}$ 맞추었다. Primer는 K260을 forward로 그리 고, 각각의 유형에 따라 K255과 K261을 reverse primer로 사용하였다 (Table 1).

$\mathrm{PCR}$ 조건은 $94^{\circ} \mathrm{C} / 5$ 분간의 cycle을 1 회, $92^{\circ} \mathrm{C} / 2$ 분, $50^{\circ} \mathrm{C}$ 12 분, $72^{\circ} \mathrm{C} / 3$ 분의 cycle을 30 회 실시하고 마지막 cycle 후 $72^{\circ} \mathrm{C} / 5$ 분간 반응시켰다. $\mathrm{PCR}$ 을 수행한 후 $5 \mu \mathrm{PCR}$ 산물 을 $2 \%$ agarose gel에 전기영동한 후 $\mathrm{EtBr}$ 에 염색하여 $\mathrm{UV}$ 하에서 확인하였다. 이 때 LEE 말단에 위치한 $\mathrm{K} 255$ 와 selC의 downstream primer인 K260을 사용하여 $418 \mathrm{bp}$ 에 서 증폭되는 경우는 $\mathrm{LEE}$ 가 selC의 ORF 394 region에 삽 입된 것을 나타내며, E. coli K-12의 selC 부위의 upstream 과 downstream primer인 K261과 K260 primer에 의하여 $529 \mathrm{bp}$ 에서 증폭되는 경우는 LEE가 삽입되지 않은 온전 한 selC 유전자를 가지는 것으로 분석하였다.

$\mathrm{HEp}-2$ 세포 부착능 시험

Cravioto 등 (23)의 방법에 따라, STEC 분리주에 대한 HEp-2 (Human epithelioma type 2 cell-line) 세포 부착형태를 조사하였다 (Fig. 1).

$\mathrm{HEp}-2$ 세포의 배양 및 처리

HEp-2 세포는 penicillin과 streptomycin, 그리고 $10 \%$ fetal bovine serum (FBS)이 포함된 DMEM (Dulbecco's modified Eagle medium, Gibco, Gaithersberg, MD, USA)으로 $37^{\circ} \mathrm{C} 5 \mathrm{CO}_{2}$ 배양기 (Forma, Marietta, $\mathrm{OH}, \mathrm{USA}$ )에서 배 양하였다. 24 well tissue culture plate (Nalge Nunc, Rochester, $\mathrm{NY}$, USA)에 직경 $13 \mathrm{~mm}$ Thermanox ${ }^{\mathrm{TM}}$ Coverslip (Nalge Nunc)을 깔고, HEp-2 세포를 $2 \times 10^{6} \mathrm{cell} / \mathrm{ml}$ 이 되도록 희 


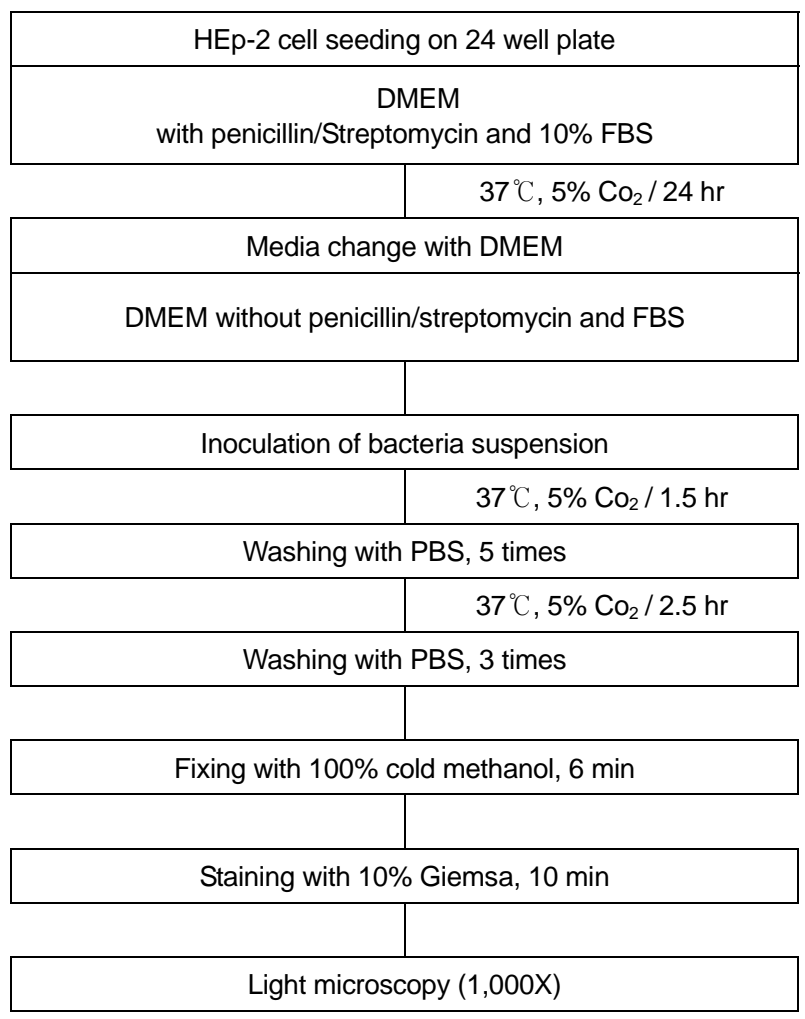

Figure 1. The procedure of HEp-2 cell adherence assay.

석하여 $1 \mathrm{ml}$ 접종하였다. 접종된 plate는 $37^{\circ} \mathrm{C}, 5 \% \mathrm{CO}_{2}$ 배 양기에서 24시간 배양하여 단층을 형성하도록 하였다. $70 \%$ 정도의 단층이 이루어지면, $\mathrm{FBS}$ 가 첨가되지 않은 $\mathrm{DMEM}$ 으로 배지를 교환하였다.

$\mathrm{HEp}-2$ 세포 부착능 시험

분리 동정된 $\mathrm{STEC}$ 는 $1 \% \mathrm{D}$-mannose가 포함된 Luria broth (Difco, Detroit, MI, USA) $5 \mathrm{ml}$ 접종하여 $37^{\circ} \mathrm{C}, 16$ 시간 동안 배양한 후, 각각의 배양액 $150 \mu \mathrm{FBS}$ 가 첨가되지 않은 $\mathrm{DMEM} 3 \mathrm{ml}$ 넣은 후 $37^{\circ} \mathrm{C}, 2$ 시간 동안 배양하였다. 배양액 각각의 균액 $100 \mu \mathrm{HEp}-2$ 세포 단층이 형성된 plate의 2 3개 well씩 접종하여 $37^{\circ} \mathrm{C}, 5 \% \mathrm{CO}_{2}$ 배양기에 서 1 시간 30 분 배양한 다음, $\mathrm{PBS}$ 로 5 회 세척한 후 $37^{\circ} \mathrm{C}$, $5 \% \mathrm{CO}_{2}$ 배양기에서 2시간 30 분 동안 배양하였다. 그 후 PBS로 3회 세척하고 $100 \%$ cold methanol을 각 well에 1 $\mathrm{ml}$ 넣고 6 분간 고정한 후, $10 \%$ Giemsa 염색액으로 20 분 간 염색을 시행하였다. 멸균증류수로 한번 세척하여 건조 시킨 후, coverslip을 well로부터 분리하여 slide glass 위에 고정시키고 광학현미경 (Carl Zeiss, Oberkochen, Germany) 으로 관찰하였다.
Table 2. Distribution of the virulence factor-encoding genes according to symptoms of the STEC isolates ${ }^{a}$

\begin{tabular}{lccc}
\hline \hline \multirow{2}{*}{ sene $^{b}$} & \multicolumn{2}{c}{ No. (\%) of isolates } & \multirow{2}{*}{ Pvalue $^{c}$} \\
\cline { 2 - 3 } & Asymptomatic & Diarrhea patients & \\
\hline saa & $70(88.6)$ & $6(14.3)$ & $<0.0001$ \\
eae & $4(5.1)$ & $31(73.8)$ & $<0.0001$ \\
ehxA & $74(93.7)$ & $33(78.6)$ & NS $(0.7803)$ \\
espP & $6(50)$ & $26(62)$ & NS $(0.5173)$
\end{tabular}

${ }^{a}$ The bfp gene and EAF plasmid were absent from all strains tested.

${ }^{b}$ The presence of the genes was determined by PCR.

${ }^{c}$ A $p$ value of $<0.05$ was considered statistically significant. $p$ values for the genes were determined by the Fisher exact test. NS, not significant.

\section{$b f p A$ 및 $\mathrm{EAF}$ 유전자에 대한 $\mathrm{PCR}$ 시험}

$b f p A$ 및 $\mathrm{EAF}$ 유전자 검출에 사용된 primer는 각각 Wieler 등 (21)과 Franke 등 (22)에 의한 것으로 Table 1과 같다.

$\mathrm{PCR}$ 반응 조성은 template DNA $5 \mu \mathrm{l}, 2.5 \mathrm{mM}$ dNTP $5 \mu \mathrm{l}$ $5 \mathrm{mM} \mathrm{MgCl}$ 가 포함된 $10 \mathrm{X}$ buffer $5 \mu \mathrm{l}$ 각각의 primer 0.5 $\mu \mathrm{l}$ 씩, $1 \mathrm{U}$ 의 Taq DNA polymerase와 멸균된 증류수로 최종 용량을 $50 \mu \mathrm{l}$ 로 맞추었다.

$b f p A$ 유전자 확인을 위한 $\mathrm{PCR}$ 조건은 $94^{\circ} \mathrm{C} / 5$ 분간의 cycle을 1 회, $94^{\circ} \mathrm{C} / 1$ 분, $57^{\circ} \mathrm{C} / 45$ 초, $72^{\circ} \mathrm{C} / 1$ 분의 cycle을 30 회 실시하고 마지막 cycle 후 $72^{\circ} \mathrm{C} / 5$ 분간 반응시켰다. $\mathrm{EAF}$ 유전자 검출을 위한 조건은 annealing 단계에서 $60^{\circ} \mathrm{C} / 2$ 분 이며 나머지는 $b f p A$ 유전자 증폭조건과 같았다. $\mathrm{PCR}$ 을 수행한 후 $5 \mu \mathrm{l}$ 의 PCR 산물을 $2 \%$ agarose gel에 전기영동 한 후 $\mathrm{EtBr}$ 에 염색하여 UV하에서 확인하였다.

\section{통계분석}

PCR 결과에 따라 GraphPad InStatversion 3.0 (GraphPad Software, Inc., La Jolla, CA, USA)을 이용하여 Fisher exact test로 유전자 보유여부에 따른 통계학적 유의성을 검정 하였으며 $p$ 값이 0.05 미만인 경우 통계적 유의성이 있 다고 판정하였다.

결 과

saa, ehxA, eae 유전자 multiplex PCR 결과

설사환자 분리주와 무증상 집단감염 분리주 및 소 분 


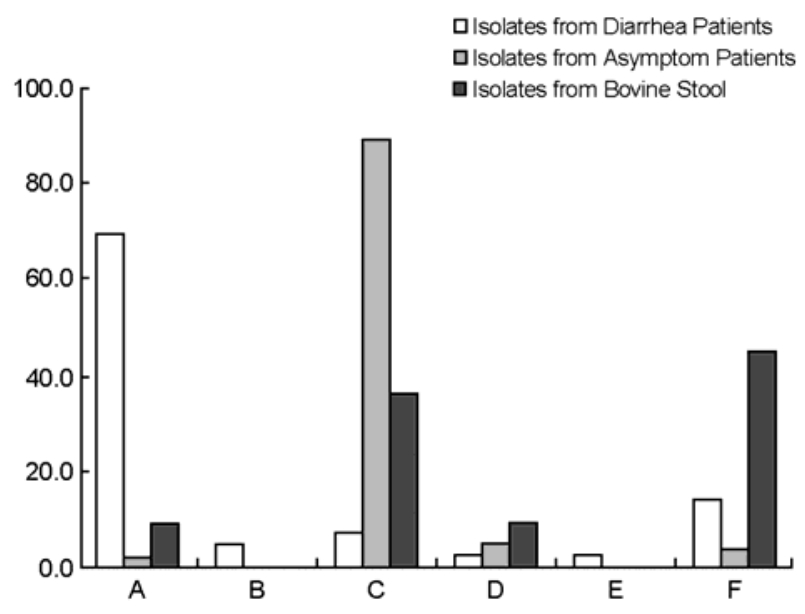

Figure 2. Distribution of the STEC genotype by multiplex PCR. A: eaeA+, ehxA+, saa-, B: eaeA+, ehxA-, saa-, C: eaeA-, ehxA+, saa+, D: eaeA-, ehxA+, saa-, E: eaeA-, ehxA-, saa+, F: eaeA-, ehxA-, saa- (+: gene present; -: gene absent).

변 유래 분리주간의 상관관계를 살펴보기 위해 $\mathrm{PCR}$ 을 실시한 결과, eae 유전자는 설사 및 식중독환자 유래 $\mathrm{STEC}$ 에서 31주 (73.8\%), 무증상 집단감염 STEC에서 4주 $(5.1 \%)(p<0.0001)$, 소 분변 유래 STEC에서 1주 $(9.1 \%)$ 가 확인되었고, saa 유전자는 설사 및 식중독환자 유래 $\mathrm{STEC}$ 에서 6주 (14.3\%), 무증상 집단감염 STEC에서 70주 (88.6\%) $(p<0.0001)$, 소 분변 유래 STEC에서 4주 $(36.4 \%)$ 가 확인되었다. $e h x A$ 유전자는 설사 및 식중독환자 유래 $\mathrm{STEC}$ 에서 33주 $(78.6 \%)$, 무증상 집단감염 STEC에서 74 주 $(93.7 \%)(p=\mathrm{NS})$, 소 분변 유래 STEC에서 6주 $(54.5 \%)$ 에서 관찰되었다 (Table 2).

이들 세 유전자의 조합으로 살펴보면 설사환자 분리 주에서는 eae+, ehxA+, saa- (genotype A)인 group이 29명 (69\%), 무증상 집단발병 분리주에서는 eae-, ehxA+, saa+ (genotype C)인 group이 68명 $(86 \%)$ 으로 가장 많은 비중 을 차지하였다. 또한 소 분변 유래 분리주에서도 eae-, ehxA+, saa+ (genotype C)인 group이 4주 $(36 \%)$ 로 가장 우 세하였다 (Fig. 2, 3).

STEC 분리주의 "attaching and effacing" 병변에 관여 하는 유전자의 특성

eae 유전자의 유형을 결정하기 위하여 eae 유전자를 가진 소 분변 유래 STEC 분리주 1주, 설사 및 식중독환 자 유래 STEC 분리주 31주, 무증상 집단감염 STEC 분 리주 1주 및 양성대조군으로 ATCC 43895 (ELD 933)을 사용하였다.

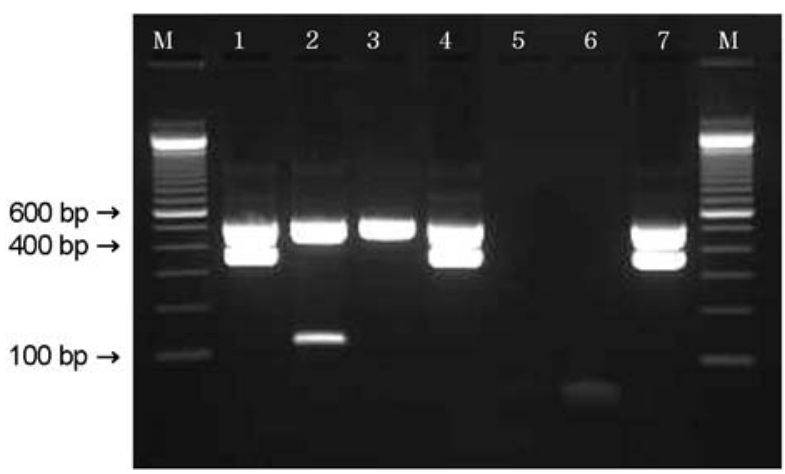

Figure 3. Multiplex PCR analysis of the saa (119 bp), eae (384 bp), the ehxA (534 bp) genes. M: 100 bp ladder, lane 1: genotype A (isolate GJ-04-08-23), lane 2: genotype C (isolate Jinwol-SBM), lane 3: genotype D (isolate bovine 20), lane 4: genotype A (isolate GJ-08-07-200), lane 5: genotyep F (isolate bovine 31), lane 6: negative control, lane 7: positive control (EDL 933).

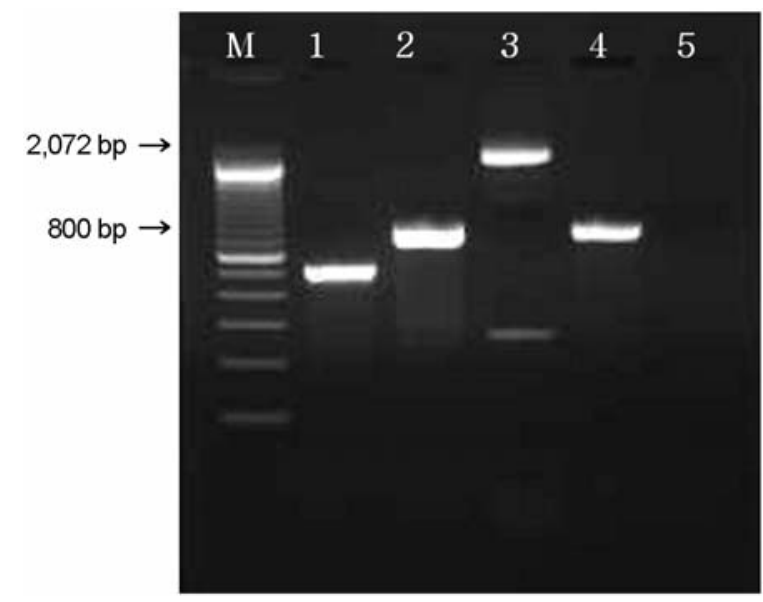

Figure 4. PCR result for the detection of $e a e_{\beta}(520 \mathrm{bp})$, eae (778 bp) and $e a e_{\varepsilon}(2,069 \mathrm{bp})$ genes. M: $100 \mathrm{bp}$ ladder, lane 1: $e a e_{\beta}$ + (isolate GJ-04-07-84), lane 2: eae + (isolate GJ-05-06-290), lane 3: eae $e_{\varepsilon}$ (isolate GJ-05-09-32), lane 4: positive control (EDL 933), lane 5: negative control.

$e a e$ 유전자의 $\alpha, \beta, \gamma, \delta$ 그리고 $\varepsilon$ 유형에 대한 PCR 결 과, 설사 및 식중독환자 유래 STEC 에서 7주 $(22.6 \%)$ 는 $e a e_{\beta}$ 유전자형, 16 주 $(51.6 \%)$ 는 $e a e_{\gamma}$ 유전자형, 그리고 3 주 $(9.7 \%)$ 는 $e a e_{\varepsilon}$ 유전자형으로 나타났다. 그러나 설사 및 식중독환자 유래 STEC 5주, 소 분변 유래 STEC 1주, 그리고 무증상 집단감염 STEC 1주에서는 밴드를 확인할 수 없었다 (Fig. 4).

혈청형별로 살펴보면 $e a e_{\beta}$ 유전자형은 $\mathrm{O} 26$ 4주, $\mathrm{O} 157$, O168, NT (non-typeable)가 각각 1주씩 확인되었고, $e a e_{\gamma}$ 유전자형은 $\mathrm{O} 157$ 과 $\mathrm{O} 111$ 이 각각 7주, $\mathrm{O} 145, \mathrm{O} 166$ 이 1주, $e a e_{\varepsilon}$ 유전자형은 $\mathrm{O} 103$ 이 2주, $\mathrm{O} 145$ 가 1주 확인되었다. 
Table 3. Virulence factors of the 67 STEC strains tested

\begin{tabular}{|c|c|c|c|c|c|c|c|c|c|c|c|c|c|c|c|c|c|c|c|c|c|}
\hline Strain & Origin & Age & Sex & $\begin{array}{c}\text { Disease } \\
\text { Association }^{\mathrm{a}}\end{array}$ & $\begin{array}{l}\text { Sero } \\
\text { Group }^{b}\end{array}$ & Sorbitol & $s t x 1$ & $s t \times 2$ & RPLA & saa & $e h x A$ & $E a e^{\mathrm{c}}$ & tir & espA & $e s p B$ & espD & espP & $b f p A$ & EAF & $S e l C^{\mathrm{d}}$ & $\begin{array}{l}\text { Adherence } \\
\text { pattern }\end{array}$ \\
\hline $27-1$ & Bovine & - & - & - & NT & - & + & - & + & + & + & - & - & - & - & - & - & - & - & I & $\mathrm{AA}$ \\
\hline 128 & Bovine & - & - & - & NT & - & - & + & - & - & - & - & - & - & - & - & - & - & - & $\mathrm{ND}$ & IS \\
\hline 153 & Bovine & - & - & - & O113 & - & - & + & + & + & + & - & - & - & - & - & - & - & - & I & LC \\
\hline 126 & Bovine & - & - & - & O117 & - & + & + & + & - & - & - & - & - & - & - & + & - & - & $\mathrm{ND}$ & IS \\
\hline 20 & Bovine & - & - & - & O168 & - & - & + & - & - & + & - & - & - & - & - & - & - & - & I & NA \\
\hline 27 & Bovine & - & - & - & O178 & - & + & + & + & + & + & - & - & - & - & - & - & - & - & D & DA \\
\hline 174 & Bovine & - & - & - & $\mathrm{O} 2$ & - & - & + & - & - & - & - & - & - & - & - & + & - & - & D & IS \\
\hline 31 & Bovine & - & - & - & $\mathrm{O} 22$ & - & - & + & - & - & - & - & - & - & - & - & - & - & - & $\mathrm{D}$ & NA \\
\hline 171 & Bovine & - & - & - & O46 & - & - & + & - & - & - & - & - & - & - & - & - & - & - & I & IS \\
\hline 180 & Bovine & - & - & - & O5 & - & - & + & - & - & + & $+(\mathrm{UT})$ & - & - & - & - & - & - & - & $\mathrm{D}$ & IS \\
\hline 189 & Bovine & - & - & - & O6 & - & - & + & + & + & + & - & - & - & - & - & + & - & - & $\mathrm{D}$ & NA \\
\hline GJ-06-07-117 & Human & 1 & M & $\mathrm{D}$ & NT & - & + & - & + & - & + & $+(\beta)$ & - & - & + & + & + & - & - & $\mathrm{ND}$ & LA \\
\hline GJ-05-06-150 & Human & 7 & M & $\mathrm{D}$ & $\mathrm{O} 103$ & - & + & - & + & - & + & $+(\mathrm{UT})$ & - & - & - & - & - & - & - & $\mathrm{D}$ & LA \\
\hline GJ-05-08-057 & Human & 2 & $\mathrm{M}$ & $\mathrm{D}$ & $\mathrm{O} 103$ & - & + & - & + & - & + & $+(\mathrm{UT})$ & - & - & - & - & - & - & - & $\mathrm{ND}$ & LA \\
\hline GJ-06-07-222 & Human & 2 & $\mathrm{~F}$ & $\mathrm{D}$ & $\mathrm{O} 103$ & - & + & - & + & - & + & $+(\mathrm{UT})$ & + & - & + & + & - & - & - & I & LA \\
\hline GJ-05-06-290 & Human & 9 & $\mathrm{~F}$ & $\mathrm{D}$ & O111 & - & + & + & + & - & - & $+(\gamma)$ & + & - & + & + & + & - & - & I & $\mathrm{LC}$ \\
\hline GJ-05-11-087 & Human & 1 & M & $\mathrm{D}$ & O111 & - & + & - & + & - & + & $+(\gamma)$ & - & - & + & + & + & - & - & I & LA \\
\hline GJ-07-07-066 & Human & 0 & $\mathrm{M}$ & $\mathrm{D}$ & O111 & - & + & + & + & - & + & $+(\gamma)$ & - & - & - & - & + & - & - & I & LA \\
\hline GJ-07-08-056 & Human & 1 & M & $\mathrm{D}$ & O111 & - & + & - & + & - & + & $+(\gamma)$ & - & - & + & - & + & - & - & I & NA \\
\hline GJ-08-07-200 & Human & 5 & M & $\mathrm{D}$ & O111 & - & + & + & + & - & + & $+(\gamma)$ & - & - & + & + & + & - & - & I & IS \\
\hline GJ-08-07-422 & Human & 1 & M & $\mathrm{D}$ & O111 & - & + & - & + & - & + & $+(\gamma)$ & - & - & - & - & + & - & - & I & LA \\
\hline GJ-08-08-147 & Human & 1 & $\mathrm{M}$ & $\mathrm{D}$ & O111 & - & + & - & + & - & + & $+(\gamma)$ & - & - & - & - & + & - & - & I & LC \\
\hline GJ-07-08-040 & Human & 0 & $\mathrm{~F}$ & $\mathrm{D}$ & O112ac & - & - & + & + & - & - & - & - & - & - & - & - & - & - & ND & IS \\
\hline
\end{tabular}


Table 3. Continued

\begin{tabular}{|c|c|c|c|c|c|c|c|c|c|c|c|c|c|c|c|c|c|c|c|c|c|}
\hline Strain & Origin & Age & Sex & $\begin{array}{c}\text { Disease } \\
\text { Association }\end{array}$ & $\begin{array}{c}\text { Sero } \\
\text { Group }^{b}\end{array}$ & Sorbitol & $s t x 1$ & $s t \times 2$ & RPLA & saa & $e h x A$ & $E a e^{\mathrm{c}}$ & tir & espA & espB & espD & espP & $b f p A$ & EAF & $\operatorname{SelC}^{\mathrm{d}}$ & $\begin{array}{c}\text { Adherence } \\
\text { pattern }\end{array}$ \\
\hline GJ-08-10-091 & Human & 1 & $\mathrm{~F}$ & $\mathrm{D}$ & O117 & - & + & - & + & - & + & $+(\mathrm{UT})$ & + & - & + & + & - & - & - & I & LA \\
\hline GJ-08-07-100 & Human & 8 & $\mathrm{M}$ & $\mathrm{D}$ & O120 & - & - & + & + & - & - & - & - & - & - & - & - & - & - & I & IS \\
\hline GJ-05-07-165 & Human & 2 & $\mathrm{M}$ & $\mathrm{D}$ & O127 & - & + & - & + & - & + & $+(\beta)$ & + & - & + & + & - & - & - & $\mathrm{ND}$ & $\mathrm{AA}$ \\
\hline GJ-08-07-205 & Human & 5 & $\mathrm{M}$ & $\mathrm{D}$ & O128 & - & + & - & + & - & - & - & - & - & - & - & - & - & - & I & NA \\
\hline GJ-04-08-23 & Human & 2 & $\mathrm{~F}$ & $\mathrm{D}$ & O145 & - & + & - & + & - & + & $+(\gamma)$ & + & + & + & + & + & - & - & I & LA \\
\hline GJ-05-09-032 & Human & 1 & $\mathrm{~F}$ & $\mathrm{D}$ & O145 & - & + & - & + & - & + & $+(\varepsilon)$ & + & + & + & + & + & - & - & I & IS \\
\hline GJ-05-11-177 & Human & 1 & $\mathrm{~F}$ & $\mathrm{D}$ & O157 & + & - & + & + & - & + & $+(\gamma)$ & - & + & + & + & + & - & - & ND & IS \\
\hline GJ-07-06-324 & Human & 1 & $\mathrm{M}$ & $\mathrm{D}$ & O157 & + & + & + & + & - & + & $+(\gamma)$ & - & + & + & + & + & - & - & $\mathrm{D}$ & IS \\
\hline GJ-07-07-088 & Human & 2 & $\mathrm{M}$ & $\mathrm{D}$ & O157 & + & + & + & + & - & + & $+(\gamma)$ & - & + & + & + & + & - & - & ND & IS \\
\hline GJ-07-07-216 & Human & 1 & $\mathrm{~F}$ & $\mathrm{D}$ & O157 & + & + & + & + & - & + & $+(\gamma)$ & + & + & + & + & + & - & - & I & LA \\
\hline GJ-07-08-210 & Human & 1 & $\mathrm{~F}$ & $\mathrm{D}$ & O157 & + & + & + & + & - & + & $+(\gamma)$ & + & + & + & + & + & - & - & ND & NA \\
\hline GJ-08-05-148 & Human & 67 & $\mathrm{M}$ & $\mathrm{D}$ & O157 & + & + & + & + & - & + & $+(\gamma)$ & + & + & + & + & + & - & - & D & IS \\
\hline GJ-05-09-110 & Human & 2 & $\mathrm{M}$ & D & O166 & - & + & - & + & - & + & $+(\gamma)$ & + & - & + & + & - & - & - & ND & IS \\
\hline GJ-05-07-078 & Human & 8 & $\mathrm{M}$ & $\mathrm{D}$ & O168 & - & - & + & - & - & + & $+(\beta)$ & - & - & - & - & - & - & - & $\mathrm{D}$ & IS \\
\hline GJ-04-07-84 & Human & 1 & $\mathrm{~F}$ & $\mathrm{D}$ & $\mathrm{O} 26$ & - & + & + & + & - & + & $+(\beta)$ & + & - & + & + & + & - & - & I & LA \\
\hline GJ-05-07-037 & Human & 2 & $\mathrm{M}$ & D & $\mathrm{O} 26$ & - & + & + & + & - & - & $+(\beta)$ & + & - & + & + & + & - & - & ND & $\mathrm{LC}$ \\
\hline GJ-05-07-164 & Human & 4 & $\mathrm{~F}$ & $\mathrm{D}$ & $\mathrm{O} 26$ & - & + & - & + & - & + & $+(\mathrm{UT})$ & - & - & - & - & + & - & - & I & LA \\
\hline GJ-05-10-167 & Human & 3 & $\mathrm{~F}$ & $\mathrm{D}$ & $\mathrm{O} 26$ & - & + & - & + & - & + & $+(\beta)$ & + & - & + & + & + & - & - & ND & LA \\
\hline GJ-07-05-219 & Human & 44 & $\mathrm{~F}$ & $\mathrm{D}$ & $\mathrm{O} 26$ & - & + & - & + & - & + & $+(\beta)$ & + & - & + & + & + & - & - & ND & LA \\
\hline GJ-08-07-438 & Human & 6 & $\mathrm{M}$ & $\mathrm{D}$ & O55 & - & + & - & - & + & + & - & - & - & - & - & + & - & - & I & IS \\
\hline GJ-07-09-032 & Human & 11 & $\mathrm{M}$ & $\mathrm{D}$ & O84 & - & + & - & - & - & - & - & - & - & - & - & - & - & - & ND & $\mathrm{LC}$ \\
\hline Gwangsan 3 & Human & - & $\mathrm{F}$ & $\mathrm{SF}$ & NT & - & - & + & + & + & + & - & - & - & - & - & + & - & - & ND & $\mathrm{LC}$ \\
\hline Jinwol 1071 & Human & - & - & $\mathrm{SF}$ & NT & - & + & - & - & - & + & - & - & - & - & - & - & - & - & ND & IS \\
\hline
\end{tabular}


Table 3. Continued

\begin{tabular}{|c|c|c|c|c|c|c|c|c|c|c|c|c|c|c|c|c|c|c|c|c|c|}
\hline Strain & Origin & Age & Sex & $\begin{array}{c}\text { Disease } \\
\text { Association }^{\mathrm{a}}\end{array}$ & $\begin{array}{c}\text { Sero } \\
\text { Group }^{b}\end{array}$ & Sorbitol & $s t x 1$ & $s t x 2$ & RPLA & saa & $e h x A$ & $E a e^{\mathrm{c}}$ & tir & espA & $\operatorname{esp} B$ & espD & espP & $b f p A$ & $\mathrm{EAF}$ & $S_{e l C}^{d}$ & $\begin{array}{c}\text { Adherence } \\
\text { pattern }\end{array}$ \\
\hline Yongdoo 29 & Human & - & - & $\mathrm{SF}$ & O103 & - & + & - & + & - & + & $+(\varepsilon)$ & + & - & + & + & - & - & - & I & LA \\
\hline KBM & Human & - & $\mathrm{M}$ & SF & O103 & - & + & - & + & - & + & $+(\varepsilon)$ & + & - & + & + & - & - & - & I & $\mathrm{LC}$ \\
\hline Jinwol 1682 & Human & - & - & $\mathrm{SF}$ & O115 & - & + & - & + & - & + & - & - & - & - & - & - & - & - & I & $\mathrm{LC}$ \\
\hline Yongdoo 26 & Human & - & - & $\mathrm{SF}$ & O141 & - & - & + & + & - & - & - & - & - & - & - & - & - & - & ND & NA \\
\hline Jinwol 457 & Human & - & - & SF & O146 & - & - & + & + & + & + & - & - & - & - & - & + & - & - & I & IS \\
\hline Jinwol 1692 & Human & - & - & $\mathrm{SF}$ & O146 & - & - & + & - & - & + & - & - & - & - & - & - & - & - & $\mathrm{D}$ & NA \\
\hline KIW & Human & - & $\mathrm{F}$ & $\mathrm{SF}$ & O157 & + & + & + & + & - & + & $+(\gamma)$ & + & + & + & + & + & - & - & $\mathrm{D}$ & IS \\
\hline Jinwol 242 & Human & - & - & $\mathrm{SF}$ & O163 & - & - & + & + & + & + & - & - & - & - & - & - & - & - & ND & NA \\
\hline DG3 & Human & - & $\mathrm{F}$ & $\mathrm{SF}$ & O168 & - & - & + & + & - & + & - & - & - & - & - & - & - & - & I & NA \\
\hline Gwangsan5 & Human & - & $\mathrm{F}$ & $\mathrm{SF}$ & $\mathrm{O} 174$ & - & - & + & + & + & + & - & - & - & - & - & + & - & - & I & IS \\
\hline Jinwol 41 & Human & - & - & $\mathrm{SF}$ & $\mathrm{O} 26$ & - & + & - & + & - & + & $+(\mathrm{UT})$ & + & - & + & + & + & - & - & ND & LA \\
\hline Yongdoo 30 & Human & - & - & $\mathrm{SF}$ & O84 & - & + & - & - & - & - & - & - & - & - & - & - & - & - & ND & NA \\
\hline Gwangsan3-2 & Human & - & $\mathrm{F}$ & $\mathrm{SF}$ & O91 & - & + & - & + & + & + & - & - & - & - & - & + & - & - & $\mathrm{D}$ & $\mathrm{LC}$ \\
\hline Jinwol-SBM & Human & - & $\mathrm{F}$ & $\mathrm{SF}$ & O91 & - & + & + & + & + & + & - & - & - & - & - & + & - & - & $\mathrm{D}$ & IS \\
\hline Jinwol 9 & Human & - & - & $\mathrm{SF}$ & O91 & - & + & + & + & + & + & - & - & - & - & - & + & - & - & $\mathrm{D}$ & IS \\
\hline Jinwol 13 & Human & - & - & $\mathrm{SF}$ & O91 & - & + & + & + & + & + & - & - & - & - & - & + & - & - & $\mathrm{D}$ & $\mathrm{LC}$ \\
\hline Jinwol 1222 & Human & - & - & $\mathrm{SF}$ & O91 & - & + & + & + & - & - & - & - & - & - & - & - & - & - & $\mathrm{D}$ & IS \\
\hline Jinwol 1269 & Human & - & - & $\mathrm{SF}$ & O91 & - & + & + & + & - & - & - & - & - & - & - & - & - & - & $\mathrm{D}$ & IS \\
\hline Jinwol 1672 & Human & - & - & SF & O91 & - & + & - & + & - & + & - & - & - & - & - & + & - & - & ND & AA \\
\hline pork & food & - & - & - & NT & - & - & + & - & - & + & - & - & - & - & - & + & - & - & I & IS \\
\hline beef & food & - & - & - & O116 & - & + & + & + & + & + & - & - & - & - & - & + & - & - & ND & IS \\
\hline
\end{tabular}

${ }^{\mathrm{a}} \mathrm{D}$; Diarrhea, SF; symptom free, ${ }^{\mathrm{b}} \mathrm{NT}$; nontypeable, ${ }^{\mathrm{c}} \mathrm{UT}$; untypeable, ${ }^{\mathrm{d}} \mathrm{ND}$; not detected 


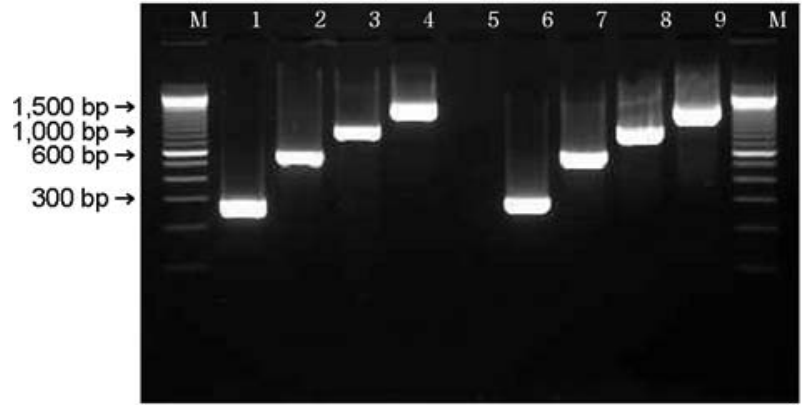

Figure 5. PCR result for the detection of espA (299 bp), espB (633 bp), espD (939 bp) and tir (1,550 bp) genes. M: 100 bp ladder, lane 1 4: espA +, espB +, espD +, tir + (isolate GJ-05-09-032), lane 5: negative control, lane 6 9: positive control (EDL 933).

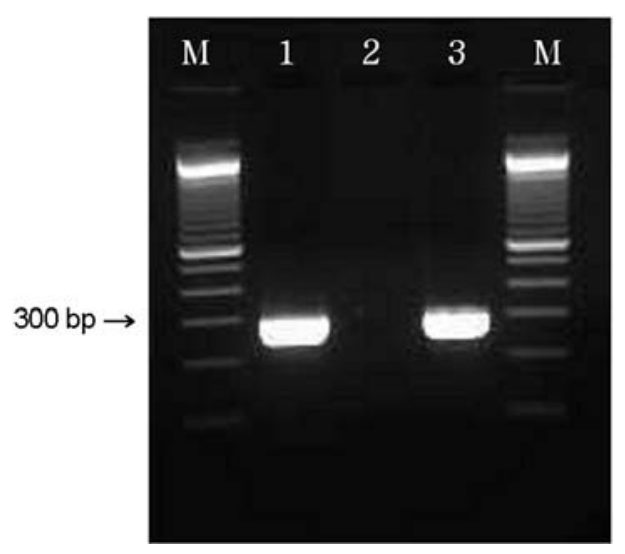

Figure 6. PCR analysis of the espP (301 bp)genes. M: $100 \mathrm{bp}$ ladder, lane 1: espP + (isolate GJ-07-06-324), lane 2: negative control, lane 3: positive control (EDL 933).

tir 유전자는 소 분변 유래 STEC에서는 확인되지 않았 으나, 설사 및 식중독환자 유래 STEC 분리주에서는 17 주 (54.8\%), 무증상 집단감염 STEC 분리주 1주 $(100 \%)$ 에 서 확인되었다. tir 유전자를 가진 분리주는 모두 eae 유전 자를 보유하고 있었으며 유형별로는 $e a e_{\beta}$ 가 5 주 $(27.8 \%)$,

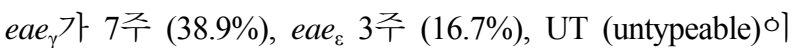
3 주 (16.7\%)였다.

$\operatorname{espA}, \operatorname{espB}, e s p D$ 유전자를 모두 가지고 있는 균주는 9주 $(29 \%)$ 로 모두 설사 및 식중독환자 유래 분리주였 다. espB 유전자는 설사 및 식중독환자 유래 STEC 24주 (77.4\%)와 무증상 집단감염 STEC 1주 $(100 \%)$ 에서 확인되 었고, $e s p D$ 는 $e s p B$ 유전자를 가진 설사 및 식중독환자 유래 STEC 1주를 제외하고 동일하게 관찰되었다 (Fig. 5 와 Table 3).

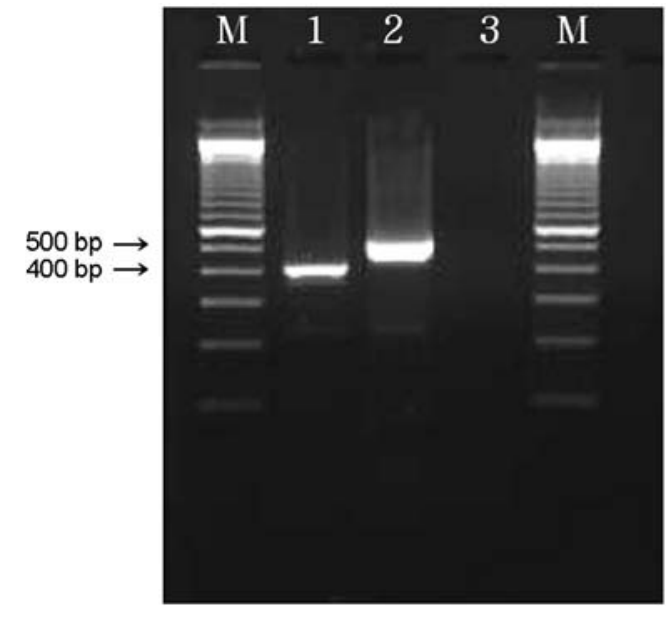

Figure 7. Multiplex PCR to distinguish an intact selC locus from one disrupted by LEE. M: 100 bp ladder, lane 1: disrupted selC (418 bp, isolate GJ-05-06-150), lane 2: Intact selC (527 bp, isolate GJ-05-06-290), lane 3: ND (not detected).

\section{espP 유전자 PCR 결과}

설사 및 식중독환자 유래 STEC에서 26주 $(62 \%)$, 무증 상 집단감염 $\mathrm{STEC}$ 에서 6주 $(50.1 \%)(p=0.339)$, 소 분변 유래 STEC에서 3주 $(18 \%)$ 가 확인되었고, 식품 분리주 중 1 건 (50\%)에서 확인되었다 (Fig. 6).

\section{$\mathrm{LEE}$ 의 염색체상의 삽입여부 $\mathrm{PCR}$ 결과}

Chromosome 내의 LEE 삽입위치를 결정하기 위해 PCR 을 실시한 결과 설사 및 식중독환자 유래 STEC 31주 중 5 주 (16\%)만이 selC 염색체에 삽입되어 있었고, 16주 (52\%)는 selC 이외의 염색체에 삽입되어 있었으며, 10 주 $(32 \%)$ 는 밴드를 확인할 수 없었다. 또한 selC에 삽입되어 있는 STEC 중 O111이 7주로 가장 많이 차지하고 있었 다 (Fig. 7).

\section{$\mathrm{HEp}-2$ 세포 부착능 시험결과}

각 분리주들의 부착에 관련된 유전자와 조직세포에서 의 실제 부착유형과의 상관관계를 살펴보기 위하여 HEp2 세포에 대한 부착능 시험을 실시하였다.

표기 방법은 세포에 세균이 매우 밀집되어 부착되어 있는 형태를 LA (localized adherence)로 표기하였고, LA 에서 보여지는 밀집된 형태와는 달리 보다 느슨하게 형 성된 군집과 산발적으로 흩어져 부착된 형태를 LC (loose clusters of bacteria)로 표기하였다. 또한 세균끼리의 군집 을 형성하지 않고 독립적으로 세포에 부착하는 양상을 

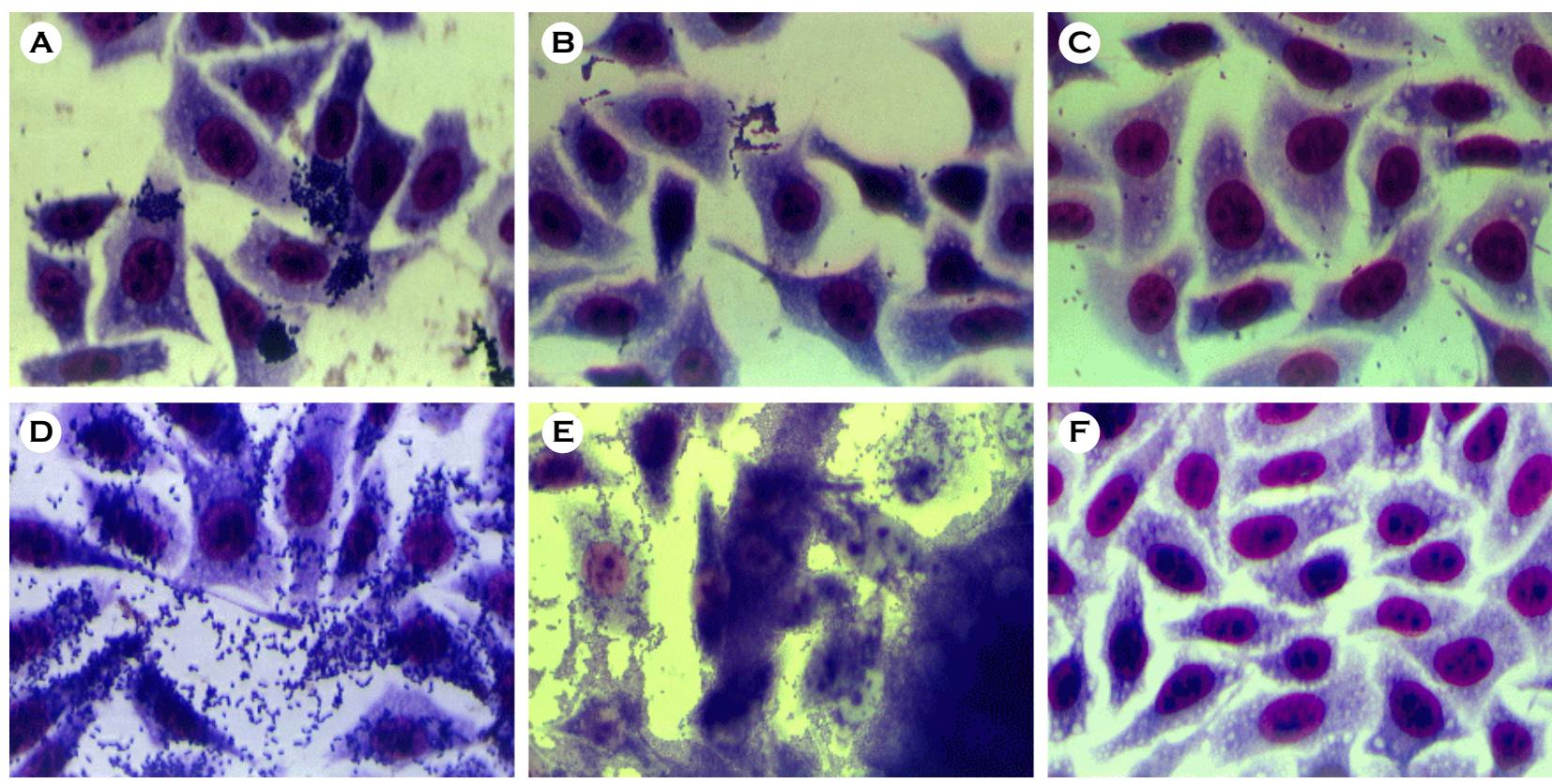

Figure 8. Adherence patterns of STEC in HEp-2 cell culture. A: LA pattern, isolate GJ-04-07-84, B: LC pattern, isolate Jinwol 9, C: IS pattern: isolate Jinwol SBM, D: DA pattern, isolate bovine 27, E: AA pattern, isolate GJ-08-07-54, F: Negative control.

IS (isolated bacteria), LA처럼 세포 한쪽에 밀집된 형태로 부착되는 것이 아니고 세포표면 전체에 부착되어 있는 모양을 DA (diffuse adherence), 세포가 아닌 곳에서도 세 균끼리 뭉쳐서 막대모양을 형성하고 세포표면에도 동일 한 모양을 형성하는 것을 AA (aggregative adherence)로 표 현하였다. 마지막으로 세균의 부착이 관찰되지 않은 것을 $\mathrm{NA}$ (not adherent)로 표기하였다 (Fig. 8).

소 분변 유래 STEC 분리주 중 4 주 $(36.4 \%)$ 에서 IS (isolated bacteria), $\mathrm{AA}, \mathrm{DA}, \mathrm{LC}$ 가 각각 1 주씩 관찰되었다. 설사 및 식중독환자 유래 STEC에서는 16 주 (38.1\%)에서 LA 표현형을, 13 주 (31\%)에서 IS 표현형, 7주 (16.7\%)에서 $\mathrm{LC}$ 표현형 그리고 1 주 $(2.4 \%)$ 에서는 $\mathrm{AA}$ 표현형을 확인 하였다. 무증상 집단감염 $\mathrm{STEC}$ 에서는 6 주 $(50 \%)$ 에서 IS 표현형을, 2 주 $(16.7 \%)$ 에서 $\mathrm{LC}$ 표현형, 각각 1주 $(8.3 \%)$ 에서 $\mathrm{LA}$ 와 $\mathrm{AA}$ 표현형을 확인하였다.

\section{고 찰}

본 연구에서는 STEC의 병인기작 및 임상증상과 관련 된 병원성 인자를 밝히고자 광주지역에서 분리된 설사 환자, 무증상감염 그리고 소 분변으로부터 분리된 STEC 를 대상으로 병원성과 관련된 유전자 발현의 차이를 관 찰하였다. $e a e, e h x A, s a a$ 유전자에 대한 multiplex $\mathrm{PCR}$ 을 실시한 결과, 설사환자 및 식중독환자 유래 STEC 40주 중에서 31 주 (73.8\%)가 eae 유전자를, 6주 (14.3\%)가 saa 유전자 를 보유하였으며, 무증상 집단감염 STEC는 saa 유전자 를 4주 $(5.1 \%)$ 가 eae 유전자를, 70 주 $(88.6 \%)$ 가 saa 유전 자를 보유하고 있었다. 소 분변 유래 분리주에서도 eae 는 1 주 $(9.1 \%)$ 에서만 확인되었으며, saa는 4 주 $(36.4 \%)$ 에 서 확인되어 무증상 집단감염 분리주와 비슷한 유전자 패턴을 나타내었다. 따라서 $\mathrm{STEC}$ 의 임상증상과 eae 유 전자 및 $s a a$ 유전자 $(p<0.0001)$ 의 통계학적 유의성을 확 인할 수 있었다. 또한 eae 유전자를 가진 균주는 모두 $s a a$ 유전자를 보유하고 있지 않아 Paton 등 (14)의 결과 와 일치함을 알 수 있었다. Schmidt 등 (11)이 ehxA 유전 자가 STEC의 병원성 인자로서의 중요성을 언급하였지 만, 그 이후 스위스 (8)와 프랑스 (9)의 연구결과에서는 병원성 균주와의 연관관계를 찾을 수 없었다. 본 연구에 서도 hemolysin 유전자인 $e h x A$ 는 증상유무나 집단간에 유전자 보유여부가 통계적으로 유의성이 없었으며, saa나 eae 유전자 보유유무와 상관없이 $50 \%$ 이상의 $\mathrm{STEC}$ 에서 확인되었다.

또한 genotype A (eaeA+, ehxA+, saa-), genotype B (eaeA+, ehxA-, saa-), genotype C (eaeA-, ehxA+, saa+), genotype D (eaeA-, ehxA+, saa-), genotype E (eaeA-, ehxA-, saa+), 
genotype F (eaeA-, ehxA-, saa-)로 유전형을 구분하였을 때, 설사 및 식중독환자 유래 STEC는 genotype A group이 29 명 $(69 \%)$, 무증상 집단발병 분리주에서는 genotype $\mathrm{C}$ 인 group이 68명 (86\%), 소 분변 유래 분리주에서도 genotype C인 group이 4주 $(36 \%)$ 로 가장 우세하였다. 또한 주요 혈청형인 $\mathrm{O} 157$ (7주), $\mathrm{O} 26$ (6주), $\mathrm{O} 111$ (7주)이 모두 genotype $\mathrm{A}$ 에 포함되어 있었다. 이로써 환자 분리주와 무 증상 집단감염 분리주와의 유전형의 차이를 확인하였고, 무증상 집단 감염주와 소 분리주와의 유전자형 분포는 비슷함을 알 수 있었다. eae 유전자와 saa 유전자 모두 병원성 STEC에서 서로 다른 기전으로 부착에 관여하는 중요한 유전인자로 알려져 있지만 (8), 본 연구에서는 saa 유전자와 병원성과의 상관관계는 규명하기 어려웠다.

$\mathrm{LEE}$ 가 결여된 $\mathrm{STEC}$ 의 plasmid에 존재하는 saa 유전 자는 (24) 세포의 외막에 위치한 자가응집 부착 단백질 이다. E. coli K-12에 saa 유전자를 형질변환한 결과 반국 소적 부착형태를 보였으며, 1998년 남호주 아델레이드 지 역의 HUS 집단발병환자로부터 분리된 O113:H21 STEC (98NK2) 균주에서 최초로 분리되었다 (25). 그리고 최근 ToxB, Sfp (sorbitol fermentating enterohemorrhagic E. coli fimbriae) 및 Iha (adherence-conferring protein similar to Vibrio cholerae $\operatorname{IrgA}$ ) 등과 같은 STEC 부착인자와 함께 중요성이 부각되고 있다 (26). 그러나 각 나라나 지역에 따라 분리주들 간의 유전자 보유여부가 상이하므로, 이 러한 병원성 유전자에 의한 단백질 발현유무나 발현 정 도의 차이를 통해, 실제 세포수준에서의 상호작용에 대한 추가연구가 필요할 것으로 생각된다.

$\mathrm{STEC}$ 는 eae 유전자에 의해 장점막에 특징적인 $\mathrm{A} / \mathrm{E}$ lesion을 형성하는데 이는 숙주세포의 미세융모 제거와 세균과 상피세포막 사이의 긴밀한 부착으로 특징지어지 며, 부착된 세균의 바로 밑에는 세포 내 골격의 현저한 변화를 보이고 때때로 pedestal-like 구조를 형성한다. 이 러한 조직병리학적부위를 "attaching and effacing" (A/E) lesion이라 명명하였다 (27). 최초로 $\mathrm{EPEC}$ 의 감염에서 관 찰되어졌으며 $\mathrm{EHEC}$ 와 일부 Hafnia alvei에 대해 실시된 동물 및 배양세포에서도 이 모양이 관찰되어졌다. 그 이 후 Adu-Bobie 등 (28)에 의해 분류된 intimin $\alpha, \beta, \gamma, \delta$ 중 intimin $\delta$ 가 intimin $\beta$ 의 아형임이 밝혀졌다 (29). ilntimin의 $\mathrm{N}$ 말단 부위는 잘 보존된 반면, Tir과 결합하는 $\mathrm{C}$ 말단 부위는 매우 다양하며 숙주 조직세포의 친화성과 연관이 깊다 (30). 주요 유전자형은 $\alpha, \beta, \varepsilon, \gamma$ 이며 (29), Iintimin $\alpha$
는 $\mathrm{EPEC}$ 에서 주로 확인되는 반면, $\gamma, \varepsilon$ 은 $\mathrm{EHEC}$, intimin $\beta$ 는 $\mathrm{EPEC}$ 와 $\mathrm{EHEC}$ 모두에서 관찰된다 (31). 따라서 STEC 병원성 인자에 대한 규명을 할 때 intimin 존재여부나 그 들의 유전자형에 대한 분석은 이루어지고 있지만, STEC 가 $\mathrm{HUS}$ 나 $\mathrm{HC}$ 와 같은 임상증상을 일으키는데 있어서 intimin의 역할에 대한 의견은 매우 다양하다 (31).

본 연구에서는 China 등 (15)과 Pradel 등 (9)의 방법에 따라, 광주지역 설사환자에서 분리된 $\mathrm{STEC}$ 에서 eae 유 전자형을 분석한 결과, $e a e_{\gamma}$ 형이 16 주 $(51.6 \%)$ 로 가장 우 세하였으며, O157, O111, O26 혈청형이 모두 이 유전자 형에 속하였다. 또한 3주에서 eae 형이 확인이 되었으며, 혈청형은 $\mathrm{O} 103$ 2주, $\mathrm{O} 145$ 1주였다. 이와 같은 결과는 프 랑스에서 HUS 환자로부터 분리된 $\mathrm{STEC}$ 의 eae 유전자형 이 $\mathrm{eae}_{\gamma}, \mathrm{eae}_{\beta}, e a e_{\varepsilon}$ 순으로 검출되었으며 (29), 설사환자에 서 분리된 STEC 균주에 대해 DNA hybridization과 PCR 방법을 이용하여 intimin 유전자의 유형을 분류한 결과에 서는 $\mathrm{eae}_{\beta 1}, \mathrm{eae}_{\varepsilon}, \mathrm{eae}_{\gamma}$ 순으로 검출됨이 보고되어 나라마 다 차이가 있음을 확인하였다 (32).

숙주 및 특정 혈청형과 intimin type의 연관성에 대하여, intimin $\alpha$ 는 classical serotypes (O55:H6, O125:H6, O127:H6 그리고 $\mathrm{O} 142: \mathrm{H} 34)$ 에 속하는 STEC 균주에서 특이적으로 발현되는 반면에, intimin $\varepsilon$ 는 사람에게서 드물게 분리되 는 STEC O103과 O121 혈청형에서만 확인되었다. Intimin $\gamma$ 역시 $\mathrm{O} 157, \mathrm{O} 111, \mathrm{O} 145, \mathrm{O} 157: \mathrm{H} 40$ 그리고 $\mathrm{I} 128: \mathrm{H} 8$ 과 같 은 nonclassical EPEC serotype과 연관이 있고 intimin $\beta$ 는 가장 흔한 유형으로서, 사람뿐만 아니라 가축과 야생동물 등에서 분리된 $\mathrm{EPEC}$ 와 $\mathrm{EHEC}$ 모두에서 확인된다 (29). 본 연구결과에서도 $\gamma$ 형에 $\mathrm{O} 157, \mathrm{O} 111, \mathrm{O} 26, \varepsilon$ 형에 $\mathrm{O} 103$, O145가 확인되어 intimin의 유형에 따라 혈청형과의 상 관관계가 매우 높음을 알 수 있었지만, 소 분변 분리주 에서는 intimin 유형이 결정되지 않아 분리 숙주에 따른 차이점은 확인할 수 없었다.

또한 $\mathrm{A} / \mathrm{E}$ 병변의 기둥다리구조 (pedestal like structure) 형성을 유도하여 세포막 actin 구조의 붕괴를 일으키는데, 이때 Tir, $\mathrm{EspB}$ 그리고 $\mathrm{EspD}$ 는 TTSS와 $\mathrm{EspA}$ 에 의해 구 조적 변형을 일으켜 숙주세포 안으로 이동한다. 숙주세 포 안으로 이동한 $\mathrm{EspB}$ 와 $\mathrm{EspD}$ 단백질은 숙주세포의 세 포질막 안으로 삽입되어 세균과 숙주세포간에 통로를 형 성한 후 다른 분자들을 숙주세포 내로 분비하여 숙주세 포 손상을 유도하여 설사를 유발한다 (33). 이러한 단백 질을 암호화 하고 있는 $t i r, e s p A, e s p B, e s p D$ 유전자 보유 
여부를 검토한 결과, intimin과 결합하는 receptor를 지령 하는 tir 유전자를 보유하고 있는 17 주 모두 eae, espB, $e s p D$ 유전자를 가지고 있었으며 espA 유전자를 보유하 고 있는 9 주에서는 모두 $e s p B$ 와 $e s p D$ 도 확인되었다. 이 는 espA, espB, espD는 같은 promotor로부터 번역되는데 기인된 결과이다 (17). 하지만 espA가 존재하지 않고 espB, $e s p D$ 만을 가지고 있거나, 이러한 TTSS 단백질을 암호화 하고 있는 유전자 없이 eae만 가지고 있는, 즉 LEE profile 이 온전하지 않은 균주들도 확인할 수 있었다. 이는 스 페인에서 사람과 동물로부터 분리된 $\mathrm{STEC}$ 와 $\mathrm{EPEC}$ 균 주를 가지고 microarray를 이용하여 eae, tir, espA, espB, $\operatorname{espD}$ 유전자의 유형을 분석한 결과와 유사하였고 (33), Yuste 등 (34)이 설사 또는 건강한 소, 양, 염소로부터 분 리한 12개의 STEC에서 PCR을 통해 eae, tir, espA, espB, $e s p D$ 유전자를 분석한 결과에서도 LEE profile이 온전하 지 않은 균주들이 확인되어 본 연구와 일치함을 알 수 있었다. 또한 intimin, Tir, EspA, EspB, EspD 등의 단백질 의 상호작용으로 $\mathrm{A} / \mathrm{E}$ lesion을 형성하므로 하나 또는 두 개 이상의 단백질의 결여는 숙주세포에 불완전하게 부착 하거나 $\mathrm{A} / \mathrm{E}$ lesion이 형성되지 않아서, 이들 유전자를 모 두 가진 균주보다는 병원성이 약할 것으로 추측된다.

다른 $\mathrm{Esp}$ 단백질 (EspA, EspB, $\mathrm{EspD})$ 과는 다르게 secreted serine protease인 EspP는 plasmid 유래이다. Schmidt 등 (35)은 in vitro에서 $\mathrm{EspP}$ 가 human coagulation factor $\mathrm{V}$ 를 파괴시키며, 실제 $\mathrm{EHEC}$ 에 감염된 6 명의 아이들 중 5 명 의 혈청에서 이 단백질이 분리하였다. 또한 Pradel 등 (9) 이 프랑스 HUS 환자로부터 분리한 STEC에서는 Esp, KatP (catalse-peroxidase), intimin이 STEC 임상증상과 매우 관계가 깊음을 보고하였다. 하지만 sorbitol 분해능이 있 는 $\mathrm{O} 157$ 분리주에서는 espP 유전자가 결여되었다는 연 구결과도 있다 (36). 이처럼 지역 분리주에 따라 이들이 병원성 인자로서의 역할은 아직 규명되지 않았다. 본 연 구에서도 설사 및 식중독환자 유래 STEC 26 주 $(62 \%)$ 와 무증상 집단감염 STEC 6주 $(50.1 \%)(p=0.339)$ 에서 espP 유전자가 확인되었으나 임상증상의 차이에 따른 통계학 적 유의성은 없었다.

STEC 균주간의 상관관계에 접근하기 위한 분자적 실 험 중의 하나가 LEE 삽입 부위에 대한 결정이다. tRNA 유전자 부위의 많은 변형 때문에 이러한 유전자의 삽입 부위가 균주간의 유전자 전달 및 동일계통임을 확인하는 데 사용되어진다. 하지만 PCR 방법은 분리균주간의 클
론성 상관관계에 대한 정보를 제공하지만 LEE가 삽입되 어진 locus를 규명하는 데는 ribotyping과 같은 추가적인 방법이 필요하다 (9). Ribotyping도 다양한 혈청형사이에 서 그들의 유전학적 거리를 측정하기는 유용하지만 동 일 혈청형에서는 규명하기 어렵다. 하지만 plasmid profile 분석법은 같은 혈청형에 속해있는 STEC 분리주들의 분 자역학적 상관관계를 확인하는데 사용되는 방법이다 (37). 본 실험에서도 LEE 삽입 부위에 대한 PCR 결과 그들의 계통학적 상관관계나 유전자 전달에 대한 정보를 파악하 기는 어려웠다. 따라서 그것에 대한 정확한 정보를 알기 위해서는 PFGE (pulsed field gel electophoresis)나 phage typing이 수행되어야 할 것이다.

설사를 일으키는 병원성 대장균의 진단에 있어서 가장 유용한 표현형적 진단 방법은 HEp-2 세포 부착능 시험 이다. HEp-2 세포에 대한 부착은 주로 3 가지의 형태, 즉 국소적 부착 (LA, localized adherence), 집합적 부착 (AA, aggregative adherence) 그리고 확산적 부착 (DA, diffuse adherence)으로 나뉜다. 그러나 Vieira 등 (38)은 부착형태 를 보다 세분화하여, 세포의 표면에 다양한 크기로 느슨 하게 뭉쳐서 세균덩어리와 개개의 세균이 산재된 부착형 태가 함께 존재할 경우를 LC (loose clusters of bacteria)라 표기하고, 보다 느슨하게 뭉쳐진 것과 아주 밀집되어 뭉쳐진 채로 부착된 세균덩어리가 공존할 경우를 $\mathrm{LCC}$ (loose and compact bacterial clusters), 그리고 세균이 뭉쳐있 지 않고 개별적으로 부착된 세포에 존재할 경우, 이를 IS (isolated bacteria)라고 명명하였다. 이러한 표기법은 단지 연구된 균주들의 부착형태의 차이를 나타내기 위한 목적 으로, 세분화한 것으로 각각의 실험자마다 다를 수 있으 며, 설사 등의 임상증상과 직접적인 상관관계는 없다.

$\mathrm{EPEC}$ 에 있어서 $\mathrm{HEp}-2$ 세포에 대한 LA 표현형의 형성 과 $b f p A$ 유전자 및 EAF plasmid (EPEC adherence factor plasmid) 사이에는 높은 일치성을 갖는 것이 일반적인 경향이었으나, EAF plasmid가 없으면서 LA를 형성하는 $\mathrm{EPEC}$ 균주의 존재도 보고되었다 $(39,40)$. 이러한 균주들 에 BFP (bundle forming pili)와 유사한 다른 부착소가 존 재하는지는 알려진 바 없으나, EAF plasmid가 결여된 균 주들에서 염색체상의 intimin을 암호화하는 eae 유전자의 증가된 발현이 HEp-2 세포상에서 LA를 유도할 수 있는 것으로 보여진다 (41). 이렇듯 $\mathrm{EPEC}$ 의 부착유형이나 인 자에 대한 연구는 그들 자체가 병원성을 나타낸다는 많 은 보고가 있지만, STEC는 아직도 이들에 대한 논란이 
많아 부착형태에 대한 연구가 미비하다. 또한 $\mathrm{EPEC}$ 나 STEC 둘 다 LEE locus에 의해 A/E lesion을 형성하지만 조절기전이나 분비되는 단백질이 많이 다르다 (42). 즉 장 점막에 이들이 부착되어진 후 $\mathrm{EPEC}$ 는 $\mathrm{BFP}$ 나 flagella에 의해 집합을 형성하여 다른 세균들을 부착하게 하여 미 세군락을 형성하지만 $(43,44), \mathrm{STEC}$ 또한 BFP나 EPEC 의 다른 부착인자들과 기능적으로 유사한 구조를 가진 단백질들의 존재로 장점막에 군락을 형성한다 (42). 본 연 구에서 증상과 무증상 환자에서 분리된 STEC 균주간의 $e a e$ 와 saa 유전자 발현의 차이가 뚜렷하여, saa 유전자를 가진 무증상 STEC 분라주의 세포 부착능이 미비하거나 없을 것이라는 가정 하에 실험을 실시하였지만, eae 유전 자를 가진 STEC 대부분이 LA 형태를 보였으며 saa 유 전자를 가진 STEC는 LC나 IS 형태가 확인되어 부착형 태에 따른 차이만 관찰할 수 있었다. 따라서 eae나 saa 두 가지 유전자만으로 부착형태와 연관짓기는 어려우며 EPEC의 부착형태에 LEE locus에 위치한 유전자 이외에 $\mathrm{BFP}$ 나 flagella가 작용하는 것처럼 $\mathrm{ToxB}, \mathrm{Sfp}$, Iha, Efa1 (EHEC factor for adherence) LPF (lomg polar fimbriae)와 같 은 $\mathrm{STEC}$ 와 관련있는 부착인자들에 대한 연구가 종합적 으로 이루어 져야 할 것이라고 판단된다 (45 50).

본 연구에서는 광주지역 설사환자 분리주와 무증상 감 염주를 대상으로 시가 독소 이외에 병원성과 관련 있는 LEE 유전자, 용혈소 등의 병원성 인자 보유 및 변이체에 대한 유전학적 특징 (병원형)을 비교 검토하여 시가 독소 생성 대장균의 병인기작을 밝혀 이를 바탕으로 장출혈성 대장균 감염증 제어를 위한 대책을 수립하는데 기초 자 료를 마련하고자 하였다. 그 결과 설사환자 분리주에서는 $e a e$ 유전자가, 무증상 집단 감염주에서는 saa 유전자가 우세한 것으로 확인되어, LEE가 결여된 STEC에서 $s a a$ 가 용혈성 요독증후군과 같은 심각한 임상증상을 일으킨다 는 연구결과 (6)와는 상이하였지만, 분리원에 따른 분리 주의 유전자 보유여부에 차이가 있으므로 향후 STEC의 병원성 여부를 판단할 때 참고 자료로 유용할 것으로 생 각된다. 또한 eae 유전자형을 관찰한 결과 $e a e_{\gamma}$ 형이 가장 많았으나, $e a e_{\beta}$ 형과 $e a e_{\varepsilon}$ 형 및 유전자 유형이 결정되지 않 은 균주들도 상당부분 있어서 이들 균주들간의 유전적 다양성이 높은 것으로 사료되어지며 $\zeta, \eta, \theta, 1$ 와 같은 새 로운 eae 유전자형 (51)에 대한 추가 검사도 요구되어진 다. 더해서 병원성과 비병원균주를 비교함으로써 시가 독 소 이외에 다른 핵심 병원성 인자의 확인을 시도하였으
나, 이는 지역이나 나라별 분리주들 간의 병원성 인자들 에 대한 통계학적 유의수준 정도가 매우 다양하게 나타 나 명확한 결론을 내리기는 어려웠다. STEC 인체감염의 가장 중요한 감염원인 소 분리주와의 비교연구에서도 혈 청형, 독소형, 유전자형이 사람 분리주와는 많은 차이가 있었다. 따라서 소에서 분리된 STEC가 모두 사람에서 병 원성을 나타내는 것이 아니며, 비록 병원성이 약하거나 없더라도 균주들 간의 유동성 DNA 전달을 통해 후천적 으로 병원성을 획득할 가능성이 우려되므로 소 이외의 가축 등에서 $\mathrm{STEC}$ 의 감염실태에 대한 연구와 지속적인 감시체계가 필요할 것으로 생각된다.

\section{Acknowledgements}

The authors give their best thanks to the staffs of the hospitals in Gwangju city for their kind contribution and help.

\section{참 고 문 헌}

1) Griffin PM, Tauxe RV. The epidemiology of infections caused by Escherichia coli O157:H7, other enterohemorrhagic E. coli. and the associated hemolytic uremic syndrome. Epidemiol Rev 1991;13:60-98.

2) Levine MM, Xu JG, Kaper JB, Lior H, Prado V, Tall B, Nataro J, Karch H, Wachsmuth K. A DNA probe to identify enterohemorrhagic Escherichia coli of O157:H7 and other serotypes that cause hemorrhagic colitis and hemolytic uremic syndrome. J Infect Dis 1987;156:175-82.

3) Gyles CL. Escherichia coli cytotoxins and enterotoxins. Can J Microbiol 1992;38:734-46.

4) Finlay BB, Rosenshine I, Donnenberg MS, Kaper JB. Cytoskeletal composition of attaching and effacing lesions associated with enteropathogenic Escherichia coli adherence to Hela cells. Infect Immun 1992;60:2541-3.

5) Jerse AE, Yu J, Tall BD, Kaper JB. A genetic locus of enteropathogenic Escherichia coli necessary for the production of attaching and effacing lesions on tissue culture cells. Proc Natl Acad Sci USA 1990;87:7839-43.

6) Paton AW, Srimanote P, Woodrow MC, Paton JC. Characterization of Saa, a novel autoagglutinating adhesin produced by locus of enterocyte effacement-negative Shiga-toxigenic Escherichia coli strains that are virulent for humans. Infect Immun 2001; 69:6999-7009. 
7) Srimanote P, Paton AW, Paton JC. Characterization of a novel type IV pilus locus encoded on the large plasmid of locus of enterocyte effacement-negative Shiga-toxigenic Escherichia coli strains that are virulent for humans. Infect Immun 2002; 70:3094-100.

8) Boerlin P, McEwen SA, Boerlin-Petzold F, Wilson JB, Johnson RP, Gyles CL. Associations between virulence factors of Shiga toxin-producing Escherichia coli and disease in humans. J Clin Microbiol 1999;37:497-503.

9) Pradel N, Bertin Y, Martin C, Livrelli V. Molecular analysis of Shiga toxin-producing Escherichia coli strains isolated from hemolytic uremic syndrome patients and dairy samples in France. Appl Environ Microbiol 2008;74:2118-28.

10) Brunder W, Schmidt H, Karch H. KatP. a novel catalaseperoxidase encoded by the large plasmid of enterohaemorrhagic Escherichia coli O157:H7. Microbiology 1996; 142: 3305-15.

11) Schmidt H, Henkel B, Karch H. A gene cluster closely related to type II secretion pathway operons of gram-negative bacteria is located on the large plasmid of enterohemorrhagic Escherichia coli O157 strains. FEMS Microbiol Lett 1997;148: 265-72.

12) Brunder W, Schmidt H, Karch H. EspP, a novel extracellular serine protease of enterohaemorrhagic Escherichia coli O157: H7 cleaves human coagulation factor V. Mol Microbiol 1997; 24:767-78

13) Kim Y-B. Studies on virulence factors and application of arbitrarily-primed polymerase chain reaction analysis to epidemiological of Escherichia coli O157:H7. J Bacteriol Virol 2001:31:123-31.

14) Paton AW, Paton JC. Direct detection and characterization of Shiga toxigenic Escherichia coli by multiplex PCR for stx1, stx2, eae, ehxA, and saa. J Clin Microbiol 2002;40:271-4

15) China B, Goffaux F, Prison V, Mainil J. Comparison of eae, tir, espA and espB genes of bovine and human attaching and effacing Escherichia coli by multiplex polymerase chain reaction. FEMS Microbiol Lett 1999;178:177-82.

16) Goffaux F, China B, Janssen L, Mainil J. Genotypic characterization of enteropathogenic Escherichia coli (EPEC) isolated in Belgium from dogs and cats. Res Microbiol 2001;151: 865-71.

17) McNally A, Roe AJ, Sompson S, Thomson-Carter FM, Hoey DE, Currie C, Chakraborty T, Smith DG, Gally DL. Differences in levels of secreted locus of enterocyte effacement proteins between human disease-associated and bovine Escherichia coli O157. Infect immun 2001;69:5107-14.

18) McDaniel TK, Jarvis KG, Donnenberg MS, Kaper JB. A genetic locus of enterocyte effacement conserved among diverse enterobacterial pathogens. Proc Natl Acad Sci USA 1995;92:1664-8.

19) Paton AW, Paton JC. Detection and characterization of Shiga toxigenic Escherichia coli by using multiplex PCR assays for stx1, stx2, eaeA, enterohemorrhagic E. coli hlyA, rfbO111, and rfbO157. J Clin Microbiol 1998;36:598-602.

20) Kobayashi H, Shimada J, Nakazawa M, Morozumi T, Pohjanvirta T, Pelkonen S, Yamamoto K. Prevalence and characteristics of Shiga toxin-producing Escherichia coli from healthy cattle in Japan. Appl Environ Microbiol 2001;67:484 -9 .

21) Wieler LH, Vieler E, Erpenstein C, Schlapp T, Steinruck H, Bauerfeind R, Byomi A, Baljer G. Shiga toxin-producing Escherichia coli strains from bovines: association of adhesion with carriage of eae and other genes. J Clin Microbiol 1996; 34:2980-4.

22) Franke J, Franke S, Schmidt H, Schwarzkopf A, Wieler LH, Baljer G, Beutin L, Karch H. Nucleotide sequence analysis of enteropathogenic Escherichia coli (EPEC) adherence factor probe and development of PCR for rapid detection of EPEC harboring virulence plasmids. J Clin Microbiol 1994;32:2460 -3 .

23) Cravioto A, Gross RJ, Scotland SM, Rowe B. An adhesive factor found in strains of Escherichia coli belonging to the traditional infantile enteropathogenic serotypes. Curr Microbiol 1979;3:95-9.

24) Paton AW, Srimanote P, Woodrow MC, Paton JC. Characterization of Saa, a novel autoagglutinating adhesin produced by locus of enterocyte effacement-negative Shiga-toxigenic Escherichia coli strains that are virulent for humans. Infect Immun 2001;69:6999-7009.

25) Paton AW, Woodrow MC, Doyle RM, Lanser JA, Paton JC. Molecular characterization of a Shiga toxigenic Escherichia coli O113:H21 strain lacking eae responsible for a cluster of cases of hemolytic-uremic syndrome. J Clin Microbiol 1999; 37:3357-61.

26) Toma C, Martinez Espinosa E, Song T, Miliwebsky E, Chinen I, Iyoda S, Iwanaga M, Rivas M. Distribution of putative adhesins in different seropathotypes of Shiga toxin-producing Escherichia coli. J Clin Microbiol 2004;42:4937-46. 
27) Moon HW, Whipp SC, Argenzio RA, Levine MM, Giannella RA. Attaching and effacing activities of rabbit and human enteropathogenic Escherichia coli in pig and rabbit intestines. Infect Immun 1983;41:1340-51.

28) Adu-Bobie J, Frankel G, Bain C, Goncalves AG, Trabulsi LR, Douce G, Knutton S, Dougan G. Detection of intimins alpha, beta, gamma, and delta, four intimin derivatives expressed by attaching and effacing microbial pathogens. J Clin Microbiol 1998:36:662-8.

29) Oswald E, Schmidt H, Morabito S, Karch H, Marche's O, Caprioli A. Typing of intimin genes in human and animal enterohemorrhagic and enteropathogenic Escherichia coli: characterization of a new intimin variant. Infect Immun 2000; 68:64-71.

30) Frankel G, Candy DC, Fabiani E, Adu-Bobie J, Gil S, Novakova M, Phillips AD, Dougan G. Molecular characterization of a carboxy-terminal eukaryotic-cell-binding domain of intimin from enteropathogenic Escherichia coli. Infect Immun 1995;63:4323-8.

31) Gyles CL. Shiga toxin-producing Escherichia coli: An overview. J Anim Sci 2007;85(13 Suppl.):E45-62

32) Bertin Y, Boukhors K, Livrelli V, Martin C. Localization of the insertion site and pathotype determination of the locus of enterocyte effacement of Shiga toxin-producing Escherichia coli strains. Appl Environ Microbiol 2004;70:61-8.

33) Garrido P, Blanco M, Moreno-Paz M, Briones C, Dahbi G, Balnco J, Balnco J, Parro V. STEC-EPEC oligonucleotide microarray: A new tool for typing genetic variants of the LEE pathogenicity island of human and animal Shiga toxinproducing Escherichia coli (STEC) and enteropathogenic $E$. coli (EPEC) strains. Clin Chem 2006;52:192-201.

34) Yuste M, Orden JA, De La Fuente R, Ruiz-Santa-Quiteria JA, Cid D, Martinez-Pulgarin S, Dominquez-Bernal G. Polymerase chain reaction typing of genes of the locus of enterocyte effacement of ruminant attaching and effacing Escehrichia coli. Can J Vet Res 2008;72:444-8.

35) Schmidt H, Zhang WL, Hemmrich U, Jelacic S, Brunder W, Tarr PI, Dobrindt U, Hacker J, Karch H. Identification and characterization of a novel genomic island integrated at selC in locus of enterocyte effacement-negative, Shiga toxinproducing Escherichia coli. Infect Immun 2001;69:6863-73.

36) Karch H, Bielaszewska M. Sorbitol-fermenting shiga toxinproducing Escherichia coli O157:H(-) strains: epidemiology, phenotypic and molecular characteristics, and microbiological diagnosis. J Clin Microbiol 2001;39:2043-9.

37) Pradel N, Boukhors K, Bertin Y, Forestier C, Martin C, Livrelli V. Heterogeneity of Shiga toxin-producing Escherichia coli strains isolated from hemolytic-uremic syndrome patients, cattle, and food samples in central France. Appl Environ Microbiol 2001;67:2460-8.

38) Vieira MA, Andrade JR, Trabulsi LR, Rosa AC, Dias AM, Rames SR, Frankel G, Gomes TA. Phenotypic and genotypic characteristics of Escherichia coli strains of nonenteropathogenic E. coli (EPEC) serogroups that carry EAE and lack the EPEC adherence factor and Shiga toxin DNA probe sequence. J Infect Dis 2001;183:762-72.

39) Bokete TN, Whittam TS, Wilson RA, Clausen CR, O'Callahan CM, Moseley SL, Fritsche TR, Tarr PI. Genetic and phenotypic analysis of Escherichia coli with enteropathogenic characteristics isolated from Seattle children. J Infect Dis 1997; 175:1382-9.

40) Scotland SM, Smith HR, Rowe B. Escherichia coli O128 strains from infants with diarrhea commonly show localized adhesion and positivity in the fluorescent-actin staining test but do not hybridize with an enteropathogenic $E$. coli adherence factor probe. Infect Immun 1991;59:1569-71.

41) Gordillo ME, Reeve GR, Pappas J, Mathewson JJ, DuPunt HL, Murray BE. Molecular characterization of strains of enteroinvasive Escherichia coli O143, including isolates from a large outbreak in Houston, Texas. J Clin Microbiol 1992;30: 889-93.

42) Roe AJ, Hoey DE, Gally DL. Regulation, secretion and activity of type III-secreted proteins of enterohaemorrhagic Escherichia coli O157. Biochem Soc Trans 2003;31:98-103.

43) Tobe T, Sasakawa C. Role of bundle-forming pilus of enteropathogenic Escherichia coli in host cell adherence and in microcolony development. Cell Microbiol 2001;3:579-85.

44) Knutton S, Shaw RK, Anantha RP, Donnenberg MS, Zorgani AA. The type IV bundle-forming pilus of enteropathogenic Escherichia coli undergoes dramatic alterations in structure associated with bacterial adherence, aggregation and dispersal. Mol Microbiol 1999;33:499-509.

45) Tatsuno I, Horie M, Abe H, Miki T, Makino K, Shinagawa H, Taguchi H, Kamiya S, Hayashi T, Sasakawa C. toxB gene on pO157 of enterohemorrhagic Escherichia coli O157:H7 is required for full epithelial cell adherence phenotype. Infect Immun 2001;69:6660-9.

46) Brunder W, Khan AS, Hacker J, Karch H. Novel type of 
fimbriae encoded by the large plasmid of sorbitol-fermenting enterohemorrhagic Escherichia coli O157:H(-). Infect Immun 2001;69:4447-57.

47) Tarr PI, Bilge SS, Vary JC Jr, Jelacic S, Habeeb RL, Ward TR, Baylor MR, Besser TE. Iha: a novel Escherichia coli O157:H7 adherence-conferring molecule encoded on a recently acquired chromosomal island of conserved structure. Infect Immun 2000;68:1400-7.

48) Nicholls L, Grant TH, Robins-Browne RM. Identification of a novel genetic locus that is required for in vitro adhesion of a clinical isolate of enterohaemorrhagic Escherichia coli to epithelial cells. Mol Microbiol 2000;35:275-88.

49) Doughty S, Sloan J, Bennett-Wood V, Robertson M, Robins-
Browne RM, Hartland EL. Identification of a novel fimbrial gene cluster related to long polar fimbriae in locus of enterocyte effacement-negative strains of enterohemorrhagic Escherichia coli. Infect Immun 2002;70:6761-9.

50) Torres AG, Giron JA, Perna NT, Burland V, Blattner FR, Avelino-Flores F, Kaper JB. Identification and characterization of lpfABCC'DE, a fimbrial operon of enterohemorrhagic Escherichia coli O157:H7. Infect Immun 2002;70:5416-27.

51) Zhang WL, Kohler B, Oswald E, Beutin L, Karch H, Morabito S, Caprioli A, Suerbaum S, Schmidt H. Genetic diversity of intimin genes of attaching and effacing Escherichia coli strains. J Clin Microbiol 2002;40:4486-92. 